\title{
Kurklareli ve İlçeleri Üzerine Bir Bibliyografya Denemesi
}

\section{Mehmet KöSE}

\section{$\ddot{O} \mathbf{z}$}

Kırklareli, ülkemizin Marmara bölgesinin Trakya kesiminde yer alan ve zirâ̂ anlamda önemli bir merkez sayılabilecek güzide şehirlerinden biridir. 2007 yılında kurulan üniversitesi, İstanbul'a olan yakınlığı, Bulgaristan sınırında olması gibi sebeplerle sürekli gelişen ve büyüyen bir görüntü arz etmektedir. Biz de bu çalışmamızda, ülkemizin bu orta ölçekli ili olan Kırklareli’ne ve ona bağlı bulunan Babaeski, Demirköy, Kofçaz, Lüleburgaz, Pehlivanköy, Pınarhisar ve Vize ilçelerine dair bir bibliyografya sunmayı amaçladık. Bibliyografyalar, genel anlamda ve geniş çaplı hazırlanabileceği gibi belirli veya sınırlı bir alanda da hazırlanabilirler. Bibliyografya hazırlamaktaki amaç o konularda çalışma yapacak olan araştırmacıların işini kolaylaştırmak ve o alana dair bir literatür taraması yapmak isteyenler için ana başvuru kaynakları oluşturmaktır. Bu çalışmada da Kırklareli ve tüm ilçelerine dair ülkemizin üniversitelerinde hazırlanmış olan yüksek lisans ve doktora tezlerinin sistematik olarak listelenmesi amaçlanmıştır. Bunu yaparken tüm tezler arasından sosyal ve beşeri bilimler alanlarıyla ilgili olanlar seçilmiş ve bunlar bibliyografya düzenine göre sıralanmıştır. Sistematik bir liste oluşturulduktan sonra ise sosyal ve beşeri bilimlerin hangi alanıyla ilgili olarak kaç tez yazıldığı, eser sahiplerinin çalışmalarını hangi konu adıyla nitelendirdikleri ve hangi üniversitelerin bu alandaki çalışmalarının ne kadar olduğu tespit edilmeye çalışılmıştır. En önemlisi de bu tezlerin ulaşılabilirlik durumları incelenmiş ve buna dair veriler sunulmuştur. Hazırlanan bu yüksek lisans ve doktora tezlerinin yıllara göre dağılımı da verilmiştir. Ayrıca hangi dilden kaç tane tez olduğu da belirtilmiştir. Tüm bu dokümanlar, üniversitelerimizde, Kırklareli’ne ve ilçelerine yönelik akademik araştırmaların niceliksel durumunu ortaya koymaktadır.

Anahtar kelimeler: Kırklareli, bibliyografya, tez, literatür, kaynakça.

\section{A Bibliographical Treatise on Kirklareli and Its Disctricts}

\begin{abstract}
Kurklareli is one of the most prominent cities in the Thrace section of Marmara Region of our country and can be considered as an important center for agricultural purposes. The university which was established in 2007 there, offers a constantly evolving and growing image due to its proximity to Istanbul and its proximity to Bulgaria. In this study, we have tried to prepare a bibliography of our country's Kırklareli and its affiliated Babaeski, Demirköy, Kofçaz, Lüleburgaz, Pehlivanköy, Pinarhisar and Vize districts. Bibliographies may be prepared in a general sense and widely, as well as in a specific or limited area. The purpose of preparing the bibliography is to facilitate the work of the researchers who will study on them and to create the main reference resources for those who want to search the literature on that area. In this study, it is aimed to list systematically the graduate and doctoral dissertations prepared at the universities of our country about Kırklareli and all the provinces. In doing so, all the theses related to social and human sciences were selected and sorted by bibliography order. After establishing a systematic list, It was tried to find out how many theses had been written in which field of social and human sciences, what subjects they describe their work
\end{abstract}

Kırklareli Üniversitesi, Sosyal Bilimler Enstitüsü, Türk Dili ve Edebiyatı ABD YL Öğrencisi, meehmeet.kosee@gmail.com [Makale kayıt tarihi: 4.1.2018-kabul tarihi: 14.4.2018] 
and how much extent of which universities work in this area. Most importantly, the availability of these theses have been examined and data on this has been presented. The range of these master and doctorate theses according to years is also given. It also states how many theses in which languages. All these documents show the quantitative status of the academic researches on Kurklareli and at the universities in its districts.

Key Words: Kırklareli, bibliographies, thesis, literature, references.

\section{Giriş}

Çağımızda bilgi, tarihte hiç olmadığı kadar önemli ve değerli bir hâle gelmiştir. Bu durum beraberinde ona ulaşmanın da önemini arttırmış ve doğru bilgiye doğru yer ve zamanda ulaşmak en az bilginin kendisi kadar önemli bir mesele haline gelmiştir. Zira bilgiye ulaşmanın ilk yolu ona nasıl ulaşılabileceğini bilmekten geçer. İşte bu noktada bibliyografya çalışmalarının daha da bir ehemmiyetli hale geldiğini söylemek mümkündür. Özellikle belirli bir konuda veya belirli bir sınırlama ile hazırlanan bibliyografyalar, o konuya meyleden bilim insanları ve araştırmacılar için bilgiye ve bilginin kaynağına ulaşma noktasında büyük fayda sağlamaktadır. Sosyal ve beşeri bilimler ise bu anlamda yüzyıllardır gelişen ve aşamalı olarak büyüyen, kendi içerisinde belli prensipleri oluşan ve bununla beraber diğer farklı disiplinlerle de temas halinde bulunan bilim alanlarıdır. Sosyal bilimlerde yapılacak olan çalışmalarda iyi bir literatür taraması yapmak, yapılacak olan çalışmanın selameti açısından elzemdir. Zira çalışma yapılacak alan hakkındaki literatür bilgisinin genişliği, meydana getirilecek eserin kalitesiyle şüphesiz ki doğru orantılı olacaktır. Bu bibliyografya çalışmasında da sınırlandırmayı yapmak amacıyla sosyal ve beşeri alanlar tercih edilmiş ve konu olarak Kırklareli ilimiz ele alınmıştır. Kırklareli, coğrafi konumu, tarihi ve doğal güzellikleri, , verimli toprakları ve dahi jeopolitik konumu gibi sebeplerle müstesna bir yere sahiptir. Kendini "Mutlu İnsanlar Kenti" olarak tarif eden Kırklareli, büyüyen üniversitesi, coğrafi, tarihi, kültürel ve doğal güzellikleriyle oluşturduğu turizm potansiyeli ve hızlı bir şekilde gelişen ilçeleriyle günden güne artan bir çekim alanı oluşturmaktadır. Bu bibliyografya çalışmasının da Kırklareli ilimiz ve bu il hakkında çalışma yapmak isteyen araştırmacılarımız için bir nebze olsun yol gösterici olacağı kanaatindeyiz.

\section{Kirklareli}

Kırklareli, Marmara Bölgesinin Ergene Ovası ve Yıldız (Istranca) bölümleri üzerinde yer alır. Türkiye’nin hudut illeri arasındadır. Batısı Edirne, kuzeyi Bulgaristan, kuzeydoğusu Karadeniz, güneyi ve güneydoğusu ise Tekirdağ ile çevrilidir. Yüzölçümü 6.550 kilometrekaredir. Karadeniz’e 60 km deniz kıyısı, Bulgaristan'a ise 180 km kara sınırı bulunmaktadır. İlimizin denize olan yüksekliği 203 metredir. Şehrin doğusu ve kuzeyi dağlık-ormanlık alanlardan, geri kalan kısmı ise genel itibariyle düz arazilerden oluşur. Bölgede kara iklim hâkim olup yazları sıcak ve kurak, kışları ise yağışlı ve sert geçer. Ergene Nehri ve Mutlu Dere'si başlıca akarsuları olup bitki örtüsü genel itibariyle ormanlık ve step özelliği göstermektedir.

Bir yandan Trakya’nın verimli ovalarının bir bölümünü kapsayan bereketli toprak arazilerini, diğer taraftan zengin orman varlığının büyük kısmını barındıran Yıldız Dağlarının büyük yüzdeliğini bünyesinde barındıran Kırklareli, bunlarla beraber 60 km civarı ve çoğu kumsal olan kıyı şeridine sahip olmasıyla da kayda değer bir turizm potansiyeline sahip olan müstesna bir ilimizdir. Kurklareli, tüm bu özellikleriyle hem Trakyalı hem de Karadenizli kabul edilir. Verimli toprakları, tarihi ve doğal güzellikleri, sanayisi, kültürel ve sanatsal dokusuyla da göze çarpmaktadır. Gelişmişlik sıralamasında 
Türkiye'nin 81 ili arasında 11., sağllk alanında gelişmişlik sıralamasında 15. ve eğitim sektöründeki gelişmişlik açısından ise 7. sırada bulunan bu müstesna şehrimiz, İstanbul'a ve Avrupa'ya komşu olan önemli bir merkezdir (T.C. Kırklareli Valiliği Çevre ve Şehircilik İl Müdürlüğü, 2016, s. 1).

Kırklareli’nin tam olarak ne zaman, nasıl ve kimler tarafından kurulduğu bilinmemektedir. Yörenin tarihi genel anlamda Trakya'nın tarihi ile paralellik arz eder. Lakin yakın civarda höyüklerin keşfedilmesi buranın tarihinin oldukça eski zamanlara dayandığını göstermektedir. Eski çağlarda Perslerin, İskitlerin, Makedonya Kralı olan Filip’in ve Galatların hakimiyeti altında kalmıştır. Ardından Roma İmparatorluğu topraklarına katılmış ve Trakya eyaleti sınırları içerisinde yer almıştır. Bu süreçten sonra yüzlerce kez farklı kavim ve devletlerce istilaya uğrayan Kırklareli ve çevresi Türklerin burayı fethiyle beraber Osmanlı topraklarına katılmıştır.

Kırklareli'nin fetih tarihiyle ilgili Osmanlı kaynaklarında net bir bilgi olmamasıyla beraber 1366-1368 yıllarında fethedildiği kabul edilmektedir. Eski adı Saranta Ekklesies olan şehrin adı Osmanlı idaresine geçtikten sonra da değiştirilmeden aynen tercümesi olan Kırkkilise olarak kullanılmış ve kayıtlara bu ismiyle geçmiştir. Kırkkilise, Rumeli eyaletinde Vize sancağına bağlı bir kaza merkezi olarak uzun yıllar kalmıştır. Tanzimat'la birlikte idari sistemde değişiklikler olmuştur. Eyalet sisteminden vilayet sistemine geçilince Kırkkilise de, Edirne vilayetine bağlı bir sancak merkezi konumuna gelmiştir. Balkan Savaşı sırasında 24 ekim 1912 tarihinde Bulgarlarca işgal edilen şehir, 21 Temmuz 1913’te kurtarılmıştır. Kurtuluş Savaşı zamanında ise 1920'de Yunan işgaline maruz kalan şehir, 1922'de kurtarılmış ve 1924 yılında il merkezine dönüştürülmüştür (Tuncel, 1988, s. 479-480).

Türkiye Büyük Millet Meclisi’nin 4 Aralık 1924 tarihli oturumunda Kırkkilise isminin değiştirilmesi gündeme gelmiş ve Kırklareli milletvekili olan Dr. Fuad Bey (Umay) tarafından şehrin isminin değiştirilmesi teklif edilmiş fakat meclisin yaptığı ilk görüşmede bu değişiklik kabul edilmemiştir. Ardından 20 Aralık 1924’te bu konu tekrar gündeme gelerek görüşülmüss ve bu defa kabul edilmiştir. Şehre, Osmanlı'nın şehir fethetmesinde büyük katkıları olan ve hepsi de şehit düşen kırk yiğidin anısına Krrklareli ismi verilmiştir (Doğruöz, 2005, s. 5). Mecliste şehrin isminin değiştirilmesi kanununun görüşülmesi sırasında çeşitli tartışmalar yaşanmıştır. Kırklareli adının yerleşik halkın nazarında manevi bir yere sahip olduğu vurgulanmıştır. Nitekim bu şehitlerin aziz hatırası adına Kırklar Baba Dergahı kurulmuştur. Bu dergah, Balkan Harbi esnasında tahrip olmasına rağmen kitabesindeki şu ibare halkın inanışını destekler niteliktedir.

Kirk kimesne şehid oldu bu yerde

Bu nam ile anıld bu belde (Akın, 1997, s. 10-11).

Türkiye İstatistik Kurumu (TÜİK) verilerine göre 31.12.2016 itibariyle Kurklareli’nin toplam nüfusu 351.684'tür. Bunun 179.122 kişisi erkek, 172.562 kişisi ise kadındır. Toplam nüfusun 248.017 kişisi il ve ilçe merkezlerinde, 103.667 kişisi ise belde ve köylerde yaşamaktadır. Kırklareli ve ilçelerinin 2016 yılı itibariyle nüfus bilgileri şöyledir:

\begin{tabular}{|c|c|c|c|c|c|}
\hline Yıl & Yer Adı & Nüfusu & Kadın Nüfusu & Erkek Nüfusu & Nüfus Yüzdesi \\
\hline 2016 & Lüleburgaz & 145.263 & 71.648 & 73.615 & $41,30 \%$ \\
\hline 2016 & Merkez & 97.626 & 48.192 & 49.434 & $27,76 \%$ \\
\hline 2016 & Babaeski & 47.950 & 23.565 & 24.385 & $13,63 \%$ \\
\hline
\end{tabular}




\begin{tabular}{|c|c|c|c|c|c|}
\hline 2016 & Vize & 27.556 & 13.541 & 14.015 & $7,84 \%$ \\
\hline 2016 & Pinarhisar & 18.580 & 8.804 & 9.776 & $5,28 \%$ \\
\hline 2016 & Demirköy & 8.464 & 3.815 & 4.649 & $2,41 \%$ \\
\hline 2016 & Pehlivanköy & 3.681 & 1.839 & 1.842 & $1,05 \%$ \\
\hline 2016 & Kofçaz & 2.564 & 1158 & 1.406 & $0,73 \%$ \\
\hline
\end{tabular}

Tablo 1. Kırklareli ve İlçelerinin Nüfus Bilgileri

Tabloda da görüldüğü üzere Lüleburgaz ilçesi Kırklareli’nin merkezinden daha kalabalık bir nüfusa sahiptir. Her anlamda büyük bir gelişme gösteren Lüleburgaz ilçesi incelediğimiz lisansüstü tezler arasında da Kırklareli'nin genelini konu alan çalışmalardan sonra en fazla çalışma yapılan ilçe olduğu göze çarpmaktadır. Yine Babaeski de nüfus olarak diğer ilçelere göre daha kalabalıktır. Kırklareli’nin son 10 yıldaki nüfus artış hızı ise istikrarsız ve inişli çıkışlı bir grafik çizmektedir. Son 10 yll içindeki en yüksek nüfus artış hızına \% 2,24 artış hızı ile 2011 yllında ulaşmıştır. Bu rakam 2016 yılında \% 1,36'dır. Kırklareli ilinin ilçeleriyle birlikte genel olarak nüfus yoğunluğu da son 10 yll içerisinde $53 / \mathrm{km}^{2}$ ile 56 $/ \mathrm{km}^{2}$ arasında artış göstermiştir (TÜİK, 2016). Tüm bu veriler, Kırklareli’nin nüfus yönünden ne durumda olduğunu ortaya koymaktadır. Yavaş yavaş gelişen ve büyüyen Kırklareli'nin, ilçeleriyle birlikte önümüzdeki süreç içinde daha fazla göç alıp gerek ziraî gerek sanayi gerekse de ticari anlamda büyüyebilecek potansiyelde olduğunu göstermektedir.

\section{Bibliyografya}

Kütüphanelerin dijitalleşmesi ve internetle birlikte sahip olunan imkanlar her ne kadar yakın zamanda bibliyografya ilmine olan ihtiyacı ortadan kaldıracak veya belirli ölçüde bu alanın önemini yitirmesini sağlayacak gibi görünse de aslında durum hiç de böyle değildir. Zira takip edilmesi güç duruma gelen bu aşırı bilgi ve sayısız materyallerin, doğru bilgi-okur yazarlığı eğitimi almış biri tarafından bile ayıklanması ve seçilmesi başlı başına bir iştir. Dolayısıyla tüm bu bilgi ve materyallerin doğru ve etkin bir biçimde kullanılması için bunların düzenli hale getirilerek kullanıcılara ulaştırılması durumu büyük bir hizmet olarak önemini korumaya muhakkak devam edecektir.

Bilindiği üzere bibliyografya ve kaynakça kelimeleri eş anlamlı kelimeler olarak kullanılmaktadır. Türk Dil Kurumu'nun neşretmiş olduğu Büyük Türkçe Sözlük’te de "Bibliyografya" maddesi için "Kaynakça" maddesine yönlendirme yapılmış ve kaynakça maddesinde ise: belirli bir konu, belirli bir yer veya sınırl bir dönemle ilgili yayınları kapsayan veya en iyileri seçen eser, tanımında bulunulmuştur (Parlatır, ve diğerleri, 1998, s. 1251). Bununla beraber bibliyografya kelimesi köken olarak Yunanca olup "kitap" manasındaki "biblion" sözcüğü ile "yazmak" anlamındaki "graphein" kelimelerinin birleşmesiyle oluşmuştur. Belli bir konudaki yayınların tümü ve belli bir konuda yazılan eserleri ve bunların inceleyen bilim dalı olarak nitelendirilmiştir. Bibliyografyalar, kitap listeleri şeklinde Ortaçağdan beri hazırlanmakta olup gerçek anlamda bir bibliyografya hazırlama ihtiyacı 15 . yüzyılın sonları ile 16. yüzyılın başlarında ortaya çıkmıştır. Bibliyografyalar, halk için gerekli olan bilgileri vermek ihtiyacıyla peyda olmuş ve bilim insanlarının özel türde bibliyografya ve kitap listeleri hazırlamaya başlamalarıyla gelişim göstererek günümüze kadar ulaşan bir bilim dalı olmuştur (Larousse, 1992, s. 176). Bibliyografya veya diğer adıyla kaynakçalar tarih boyunca bilimle doğru orantılı olarak gelişmiş ve sistematik bilgi sunmada, gerek halk için gerekse bilim insanları ve araştırmacılar için her zaman ana başvuru kaynakları olmuşlardır. 
$\mathrm{Bu}$ çalışmamızda, incelediğimiz onlarca eserin neredeyse tamamında ittifak edilmiş olan bibliyografya yazım şekline riayet ettiğimizi belirtmek isterim. Bu çalışma sadece lisansüstü tezleri kapsadı̆̆ için incelenen örneklerde sadece bu türün bibliyografik listeleme şekillerine bakılmış ve ortak kullanım şekli baz alınmıştır. Onlar da şöyledir:

- Yazarın soyadı

- Yazarın adı

- Eser adı

- Yazıldı̆̆ üniversite

- Kabul edildiği enstitü

- (Varsa) Ana bilim dalı

- (Varsa) Bilim Dalı

- Yazıldığı şehir

- Yazıldığı tarih

\section{Sosyal ve Beşeri Bilimler}

Sosyal ve beşeri bilimler en genel tanımıyla: İnsanı, toplumu ve daha ziyade insan-insan, insan-eşya ve insan-toplum ilişkilerini bilimsel yöntemlere uygun biçimde inceleyerek üretilmiş düzenli bilgilerin bütünüdür. Sosyal gerçekliğin anlaşılması ve yorumlanması neticesinde üretilmiş olan sistematik her türlü beşerî bilgiler bütünü (Demir \& Acar, 1992, s. 328). Ayrıca matematik, fizik, kimya, tıp, astronomi vb. gibi pozitif, tabiat ve fen bilimlerinden farklı olarak, insanların etkisiyle oluşan sosyal yaşamın, sosyal olayların, sosyal düzen ve genel manada sosyal dünyanın anlam ve önemini, sosyal teoriler kapsamında sistematik bir ölçü rehberliğinde inceleyen ve açıklayan bilim dallarıdır. Bazı araştırmacılarca 19. yüzyıldan itibaren modernleşme süreciyle birlikte Batıda ortaya çıtı̆̆ı ve kurumsallaştığı varsayılmaktadır. Sosyal bilimler, insanı, toplumu ve ağırlıklı olarak bireyler arası ilişkileri, birey, sosyal ve maddi çevre münasebetlerini ve bunlardan oluşan problemleri uygun bilimsel araçlarla inceler (Seyyar, 2002, s. 483-484).

Bu çalışmayı sosyal ve beşeri alanlarla sınırlayarak aslında bu alanlarda çalışma yapacak olan bilim insanları ve araştırmacılar adına kaynaklara ve elde edilen verilere daha rahat ulaşabilme imkanı sağlamayı amaçladık. Bununla beraber, sosyal ve beşeri bilimlerin yetkin olduğumuz alanımıza daha uygun olması, bu yönde bir çalışmanın yapılmamış olması ve bilimsel makale sınırları dahilinde daha verimli bir sonuç elde etmeyi umuyor olmamız, bizi bu sınırlandırmayı yapmaya yönlendirmiştir. Peki sosyal ve beşeri alanların sınırları nelerdir? Hangi alanları, anabilim ve bilim dallarını kapsamaktadır? $\mathrm{Bu}$ çalışmada bunların hangilerine riayet edilmiştir? Şüphesiz bu soruların cevapları çalışmanın amaç ve sonucuyla doğrudan ilişkilidir. Üstelik ana hedefimiz olan "bilim insanları ve araştırmacılara belirli bir konuda bir kaynak oluşturma, veri sunma” fikrinin geçerliliği açısından da bu soruların cevaplarını vermek durumundayız.

Sosyal ve beşeri bilimlerin sınırlarının ne olup ne olmadığı tartışması uzun zamanlardır tartışılagelen ihtilaflı bir konu olmuştur. Bazı araştırmacılara göre bunu 2 başlık altında incelemek mümkündür:

I. Tam anlamıla (dolaysız) sosyal bilim dalları: Tarih, iktisat, hukuk ve siyaset gibi ilk zamanlarda felsefe-din bilimi içinde yer bulan klasik sosyal bilimler ve 19. Yüzyıldan itibaren aydınlanma çağıyla birlikte felsefeden ayrılarak müstakil bir hüviyet kazanan ve sosyal gerçekliğin farklı boyutlarıyla ilgilenen 
modern sosyal bilimler (Örn.: Kriminoloji, Sosyoloji, Sosyal Antropoloji, Çalışma Ekonomisi ve Sosyal Siyaset vb. gibi)

II. Yarı sosyal bilimler veya sosyal etkileri olan (dolaylı) sosyal bilim dalları: Felsefe, Psikoloji, Sosyal Coğrafya, Dilbilimi, Sanat, Sosyal Pedagoji, Sosyal Patoloji, Gerontoloji (Yaşlılar Bilimi) Çalışma Psikolojisi vb. gibi (Seyyar, 2002, s. 484).

Sosyal bilimlerin gerek isimlendirilmesinde gerekse alanlarının sinırlarının belirlenmesinde akademisyenler, uzmanlar ve bilim üreten kurumlar arasında ihtilaflar olduğunu daha önce de söylemiştik. Nitekim sosyal bilimlerin, özellikle de sosyoloji, psikoloji ve antropoloji gibi bilim dallarından ötürü bazen davranış bilimleri olarak da tanımlandığını görmekteyiz. Bunun yanında, bazı tasniflerde bu alanların; beşerî bilimler, sosyal bilimler ve davranış bilimleri olarak 3 başlık altında ayrı ayrı kategorize edildiğine şahit oluyoruz. Elbette bu durumun oluşmasında sosyal bilimlerin, temel doğa ve fen bilimleri gibi ölçülebilir somut verilerden beslenmemesi, insan ve toplum gibi sürekli değişkenlik gösteren, niceliksel bir varlık sahasıyla ilgilenmesi doğrudan etkilidir. O yüzden de sosyal bilimlerde kesinlik söz konusu değildir. Gerçi bakış açımızı değiştirecek olursak doğa bilimlerinde de bir kesinliğin söz konusu olmadığını görürüz. Zira kesinlik, bilimin durağanlaşmasına sebep olur ki, bu da bilimin dinamikliğine aykırı bir durumdur. Çünkü sahip olduğumuz ve doğru kabul ettiğimiz bilgiler an itibariyle sahip olduğumuz bilgilerdir ve yeni bir teoremle aksi ispatlanıp yıkılana kadar geçerlidir. Şüphesiz bu durumun sosyal ve beşeri bilimler için daha bir geçişkenlik arz ettiği aşikardır.

$\mathrm{Bu}$ çalışmayı hazırlarken kapsamı belirlemek için incelediğimiz tüm kaynaklardan ve genel geçer kabul edilen sosyal ve beşeri bilimler alanlarından aşağıda sıraladığımız alanları baz aldığımızı belirtmek durumundayı:

- Antropoloji

- Arkeoloji

- Bilgi Yönetimi

- Coğrafya

- Dilbilim

- Dini Araştırmalar

- Edebiyat

- Eğitim Bilimleri

- Ekonomi ve İşletme

- Felsefe

- Halkla İlişkiler

- Hukuk

- İletişim

- Kamu Yönetimi

- Kütüphanecilik ve Bilişim

- Müzikoloji

- Psikiyatri

- Psikoloji

- Sanat

- Sanat tarihi

- Siyasal Bilgiler

- Sosyoloji 
- Tarih

- Turizm

- Ulaşım ve Trafik

- Uluslararası İlişkiler

Belirlemiş olduğumuz bu sosyal ve beşeri bilimlerle ilgili Kırklareli ve ilçeleri üzerine yapılmış olan yüksek lisans ve doktora tezlerinin bibliyografyası şu şekildedir:

\section{Yüksek Lisans Tezleri}

1. AKARDERE UZUN, ÇİĞDEM, 1998-1999 Yilına Ait Kirklareli Vize İlçesi Çavuşköy'de Arazi Kullanım ve Araziden Yararlanma, İstanbul Üniversitesi, Sosyal Bilimler Enstitüsü, İstanbul, 1999.

2. AKDAĞ, AYSUN, Tarih Öncesi Dönem Açı Hava Müzesi Teşhirleri ve Kırklareli Aşağı Pınar Projesi'nde Uygulama Modeli, Ylldız Teknik Üniversitesi, Sosyal Bilimler Enstitüsü, İstanbul, 2002.

3. AKYÜZOĞLU, DAVUT, Anadolu Öğretmen Liselerini Tercih Eden Öğrencilerin Beklentileri ve Bu Beklentilerin Gerçekleşme Düzeyi(İstanbul, Ankara ,Düzce, Bolu, Karklareli Örneği), Yeditepe Üniversitesi, Sosyal Bilimler Enstitüsü, Eğitim Yönetimi ve Denetimi Anabilim Dalı, İstanbul, 2008.

4. ALTUNTAŞ, MEHMET, Karklareli'ndeki Türk Devri Yapılar,, Selçuk Üniversitesi, Sosyal Bilimler Enstitüsü, Konya, 1995.

5. ATICI, DİLEK. Kofçaz Ăğzı (İnceleme-Metinler-Sözlük), Trakya Üniversitesi, Sosyal Bilimler Enstitüsü, Türk Dili ve Edebiyatı Anabilim Dalı, Türk Dili Bilim Dalı, Edirne, 2016.

6. AYDIN, AYKUT, Yoksullukla Mücadelede Sosyal Yardımlaşma ve Dayanışma Vakıflarmm Etkileri: Krrklareli İli Örneğgi, İstanbul Üniversitesi, Sosyal Bilimler Enstitüsü, Endüstri İlişkileri ve İnsan Kaynakları Anabilim Dal, İstanbul, 2013.

7. BALCI, ALİ, Kurklareli İlinin Coğrafi Etüdü, Marmara Üniversitesi, Eğitim Bilimleri Enstitüsü, İstanbul, 2001.

8. BAYRAKTAROĞLU, ELÇIN, KOBİ' ler İçin UFRS Taslağının Edirne ve Karklareli İllerindeki Muhasebe Meslek Mensuplarn Tarafindan Değerlendirilmesi, Trakya Üniversitesi, Sosyal Bilimler Enstitüsü, İşletme Anabilim Dalı, Edirne, 2012.

9. BİNGÖL, GÜLSEN, Stres ve Stres Yönetimi Yaklaşımları: Krrklareli Devlet Hastanesi Hemşireleri Örneği, Beykent Üniversitesi, Sosyal Bilimler Enstitüsü, İşletme Yönetimi Anabilim Dalı, Hastane ve Sağlık Kur. Yön. Bilim Dalı, İstanbul, 2013.

10. BÜLBÜL, ALPARSLAN, Să̆hk Çalsşanlarmda Zaman Yönetimi (Krrklareli Örneği), Beykent Üniversitesi, Sosyal Bilimler Enstitüsü, İşletme Yönetimi Anabilim Dalı, Hastane ve Sağlık Kur. Yön. Bilim Dalı, İstanbul, 2014.

11. CAN, AHMET, Akademik Personelin Tükenmişlik Düzeylerinin İncelenmesi, Krrklareli Üniversitesi Örneği, Kırklareli Üniversitesi, Sosyal Bilimler Enstitüsü, İşletme Anabilim, Kırklareli, 2015.

12. CIDAN, AYDIN, Prnarhisar'da Şehirsel Gelişim, İstanbul Üniversitesi, Sosyal Bilimler Enstitüsü, Coğrafya Anabilim Dalı, İstanbul, 2017.

13. ÇABAZ, YÜKSEL, İlköğrretim 5. Sinıf Öğgrencilerinin Yazzl Anlatmlarmdaki Aktif Kelime Servetinin Belirlenmesi (Krrklareli/Merkez Örneği), Afyon Kocatepe Üniversitesi, Sosyal Bilimler Enstitüsü, Türkçe Eğitimi Anabilim Dalı, Afyon, 2007. 
14. ÇERÇI, SEYHAN, Hastane Enfeksiyonlar ve Hemşirelerin Hastane Enfeksiyonlarınm Önlenmesine İlişkin Bilgi Düzeyleri (Kırklareli Örneği), Beykent Üniversitesi, Sosyal Bilimler Enstitüsü, İşletme Yönetimi Anabilim Dalı, Hastane ve Sağlık Kur. Yön. Bilim Dalı, İstanbul, 2014.

15. ÇEVIK, AKIF, Trakya Paşaeli Cemiyeti ve Lüleburgaz-Edirne Kongreleri, Trakya Üniversitesi, Sosyal Bilimler Enstitüsü, Tarih Anabilim Dalı, Edirne, 2015.

16. ÇOLAK, ÖMER, XIX. Yüzyılın İlk Yarısında Kırkkilise Kazâsı'nın Müslim Nüfusu, Ondokuz Mayıs Üniversitesi, Sosyal Bilimler Enstitüsü, Tarih Anabilim Dalı, Samsun, 2015.

17.DEMIRALP, OZAN, Krrklareli İli Milli Ĕ̆itim Müdürlüğğ̈'nde Çalsşanlarm Memnuniyet Düzeyi, Trakya Üniversitesi, Sosyal Bilimler Enstitüsü, Eğitim Bilimleri Anabilim Dalı, Eğitim Yönetimi ve Denetimi Bilim Dalı, Edirne, 2006.

18. DENIZ, EMEL, Kırklareli Konut Yapılarmda Kalemişi Süslemeler, Çanakkale Onsekiz Mart Üniversitesi, Sosyal Bilimler Enstitüsü, Sanat Tarihi Anabilim Dalı, Çanakkale, 2016.

19. DERTLI, ADEM, Temettüat Defterlerine Göre Krklareli'nin Sosyo Ekonomik Yapısı: Karakaş, Cami-i Kebir, Yaprakh, Hatice Hatun ve Ermeni Mahalleleri, Kırklareli Üniversitesi, Sosyal Bilimler Enstitüsü, Tarih Anabilim Dalı, Kurklareli, 2015.

20. DURAK, GÖKHAN, Üniversitelerde Verilen Muhasebe Ĕ̆gitiminin Kırklareli Yöresi'nde Faaliyet Gösteren Küçük ve Orta Büyüklükteki İşletmelerin Beklentilerini Karşılama Düzeyinin İncelenmesi, Trakya Üniversitesi, Sosyal Bilimler Enstitüsü, İşletme Bölümü, İşletme Anabilim Dalı, İşletme Bilim Dalı, Edirne, 2009.

21. DURMAZ, AYŞE, Liselerde Okul Yaşam Kalitesi (Krrklareli İli Örneği), Trakya Üniversitesi, Sosyal Bilimler Enstitüsü, Eğitim Bilimleri Bölümü, Eğitim Bilimleri Anabilim Dalı, Eğitim Yönetimi, Teftişi, Planlaması ve Ekonomisi Bilim Dalı, Edirne, 2008. 22. EĞRI, TAHA, 2000 Yıh Sonrası Türk Tarm Politikalarmm Değişimi ve Bir Alan Çalsşması: Krrklareli İli Örneği, İstanbul Üniversitesi, Sosyal Bilimler Enstitüsü, İktisat Anabilim Dalı, İktisat Politikası Bilim Dalı, İstanbul, 2011.

23. EKŞİ GÖRPEOĞLU, GÖNÜL, Vize Deresinin Hidrografik Özellikleri, İstanbul Üniversitesi, Sosyal Bilimler Enstitüsü, İstanbul, 2002.

24. ERDER, ALPARSLAN, Babaeski İlçesi Kumrular Köyünde Araziden Faydalanma, İstanbul Üniversitesi, Sosyal Bilimler Enstitüsü, İstanbul, 1997.

25. ERGINAL, GÜLSEN, Limanköy (Krrklareli İli) - Malatra Burnu (İstanbul ili) Arasındaki Kıyılar ve Çevresinin Turizm Coğrafyass, Çanakkale Onsekiz Mart Üniversitesi, Eğitim Bilimleri Enstitüsü, Ortaöğretim Sosyal Alanlar Eğitimi Anabilim Dalı, Coğrafya Ĕ̆itimi Bilim Dalı, Çanakkale, 2013.

26. EROL, İLKNUR, Sağhk Çahşanlarnda Obezite Düzeyi Değerlendirilmesi (Krrklareli Örneği), Beykent Üniversitesi, Sosyal Bilimler Enstitüsü, İşletme Yönetimi Anabilim Dalı, Hastane ve Sağllk Kur. Yön. Bilim Dalı, İstanbul, 2014.

27. GENERAL, CAN AHMET, Siyasal Pazarlamada Tutundurma Faaliyetlerine İlişkin Seçmen Davrantşları: Kurklareli Örneği, Kahramanmaraş Sütçü İmam Üniversitesi, Sosyal Bilimler Enstitüsü, İşletme Anabilim Dalı, Kahramanmaraş, 2013. 
28. GÖL, EZGİ, Ilköğretim Okul Yöneticilerinin Yenilik Yönetimi Yeterliklerine İlişkin Öğretmen Algıları (Kurklareli İli Örneği), Trakya Üniversitesi, Sosyal Bilimler Enstitüsü, Eğitim Bilimleri Anabilim Dalı, Eğitim Yönetimi, Teftişi, Planlaması ve Ekonomisi Bilim Dalı, Edirne, 2012.

29. GÜÇTEKIN, NURI, 1844 (126o) Temettu'at Defterlerine Göre Krrklareli Kazasınm Karaca İbrahim Hacn Zekeriya, ve Dellakzade Mahallelerinin Sosyal ve Ekonomik Durumu, Hacettepe Üniversitesi, Sosyal Bilimler Enstitüsü, Tarih Anabilim Dalı, Ankara, 2004.

30. GÜRFIDAN, CEMILE, Aile Hekimliğine İlişkin Bilgi Beklenti ve Memnuniyet (Krrklareli İl Merkezi Örneği, Beykent Üniversitesi, Sosyal Bilimler Enstitüsü, İşletme Yönetimi Anabilim Dalı, Hastane ve Sağlık Kur. Yön. Bilim Dalı, İstanbul, 2014.

31. HÜNERLİ, BÜLENT, Krrklareli Babaeski Merkez İlçesi ve Köyleri Ăğz Íncelemesi, Trakya Üniversitesi, Sosyal Bilimler Enstitüsü, Edirne, 2006.

32. İNCE, YUSUF, İnanç Turizmi Potansiyeli Açısından Krrklareli ìl ve İlçelerinin Değerlendirilmesi, Kırklareli Üniversitesi, Sosyal Bilimler Enstitüsü, Turizm İşletmeciliği Anabilim Dalı, Kırıklareli, 2017.

33. I IPEK, EDİ, Temettuât Defterlerine Göre Babaeski, Kırklareli Üniversitesi, Sosyal Bilimler Enstitüsü, Tarih Anabilim Dalı, Kırklareli, 2014.

34. KABAKCI, BURCU BURNAZ, Xix. Yüzyıl Ortalarmda Krrklareli (Krrkkilise)'De Sosyal ve Ekonomik Hayat, İstanbul Üniversitesi, Sosyal Bilimler Enstitüsü, Tarih Anabilim Dalı, Yakınçağ Tarihi Bilim Dalı, İstanbul, 2013.

35. KADIOĞLU, MEHMET ERDİNÇ, Karklareli İlinde Yaygm Olarak Kullanılan Halk Oyunlarn Ezgilerinin Ritmik Yaptlarmm İncelenmesi, İstanbul Teknik Üniversitesi, Sosyal Bilimler Enstitüsü, İstanbul, 1993.

36. KARACA, PINAR ÖZDEMIR, İlköğretim 8. Sinff Öğrencilerinin İnovasyon Fikirleri Geliştirmelerini Etkileyen Engeller ve Teşviklerin Belirlenmesi: Kırklareli İli Lüleburgaz İlçesi Örneğ i, Gazi Üniversitesi, Eğitim Bilimleri Enstitüsü, Büro Yönetimi Eğitimi Anabilim Dalı, Ankara, 2011.

37. KARADAĞ, NAZAN, Tükenmişlik ve İş Doyumu: Krrklareli Devlet Hastanesi Hemşireleri Örneği, Beykent Üniversitesi, Sosyal Bilimler Enstitüsü, İşletme Yönetimi Anabilim Dalı, Hastane ve Sağlık Kur. Yön. Bilim Dalı, İstanbul, 2013.

38. KARAKUZU, SARIYE, Sağhk Bakanhğı'nda Organizasyonel Değişim ve Korklareli Să̆lık Çahşanlarında 663 Sayıh Sağhk Bakanh̆̆g ve Bağh Kuruluşlarmm Teşkilat ve Görevleri Hakkinda Kanun Hükmünde Kararnamenin Bilinirliği, Beykent Üniversitesi, Sosyal Bilimler Enstitüsü, İşletme Yönetimi Anabilim Dalı, Hastane ve Sağlık Kur. Yön. Bilim Dalı, İstanbul, 2013.

39. KAŞTAN, YÜKSEL, Devlet Yaturmlarmm Bölgeler Arası Dă̆ılımı Sorunsah (Antalya, Aydın, Çankur, Diyarbakur, Erzurum Kirklareli, Ordu), Hacettepe Üniversitesi, Atatürk İlkeleri ve İnkılap Tarihi Enstitüsü, Atatürk İlkeleri ve İnkılap Tarihi Anabilim Dalı, Ankara, 2002.

40. KAT, ZAFER, II. Dünya Savaşı Sonrası Trakya'da Yeşilyurt Gazetesine Göre Krrklareli (1946), Kurklareli Üniversitesi, Sosyal Bilimler Enstitüsü, Tarih Anabilim Dalı, Kırıklareli, 2016.

41. KAVAK, SIMEN, Krrklareli Monografyası, Trakya Üniversitesi, Sosyal Bilimler Enstitüsü, Edirne, 1995. 
42. KAYMAZ, OYA ESIN, Krrklareli Şehri, İstanbul Üniversitesi, Sosyal Bilimler Enstitüsü, İstanbul, 1995.

43. KIRTIL, MELEK, Pomaklar Üzerine Sosyolojik Bir Araşturma: Krrklareli Örneği, İstanbul Üniversitesi, Sosyal Bilimler Enstitüsü, Sosyoloji Anabilim Dalı, İstanbul, 2016.

44. KIVILCIM, TÜLIN, Vize Şehri, İstanbul Üniversitesi, Sosyal Bilimler Enstitüsü, İstanbul, 1998.

45. KOCAAGA, OSMAN, Siyasi Partilerde Seçim Kampanyalarmm Finansmanı: Krrklareli Örneği, Dokuz Eylül Üniversitesi, Sosyal Bilimler Enstitüsü, Kamu Yönetimi Anabilim Dalı, Kamu Yönetimi Bilim Dalı, İzmir, 2011.

46. KONYAR, BETÜL, Krrklareli İl Merkezi Yer Adlar İncelemesi, Kırklareli Üniversitesi, Sosyal Bilimler Enstitüsü, Türk Dili ve Edebiyatı Anabilim Dalı, Kırklareli, 2016.

47. KULELİ, İLKNUR, İlkokullarda Anne ve Baba İlgisinin Çocuklarm Başarısı Üzerine Etkileri (Krrklareli İli Örneği), Dokuz Eylül Üniversitesi, Eğitim Bilimleri Enstitüsü, Eğitim Bilimleri Anabilim Dalı, Eğitim Programları ve Öğretim Bilim Dal, İzmir, 2015.

48. KULOĞLU, YUNUS, Genç Kuşakta Riskli Sağhk Davranışları (Kurklareli Üniversitesi Öğgrencileri Örneği), Beykent Üniversitesi, Sosyal Bilimler Enstitüsü, İşletme Yönetimi Anabilim Dalı, Hastane ve Sağlık Kur. Yön. Bilim Dalı, İstanbul, 2015.

49. KURTÇU, EMEL, Krrklareli İlinde Konuşlanmış Sanayi İşlettmelerinin İstihdam Problemleri Üzerine Bir Analiz, Trakya Üniversitesi, Sosyal Bilimler Enstitüsü, Edirne, 1997.

50. MENTEŞ FIRAT, Bulgaristan Türklerinin Dini Ĕgilimleri ve Sorunlar: 1989-199o'da Lüleburgaz'a Yerleşenler Örneği, Ankara Üniversitesi, Sosyal Bilimler Enstitüsü, Felsefe ve Din Bilimleri Anabilim Dalı, Din Sosyolojisi Bilim Dalı, Ankara, 2011.

51. MERCAN MORGÜL, ŞÜKRAN, Trakya Bölgesinde Karsal Turizm Potansiyelinin Değerlendirilmesine İlişkin Analiz: Korklareli Örneği, Trakya Üniversitesi, Sosyal Bilimler Enstitüsü, Edirne, 2006.

52. MUTLUER, GÜLBAHAR, Krkklareli Müzesinde Bulunan Hesap İşi ve Türk İşi Tekniği İle Çalsşılmış Ürünlerin Değerlendirilmesi, Gazi Üniversitesi, Eğitim Bilimleri Enstitüsü, El Sanatları Eğitimi Anabilim Dalı, Nakış Eğitimi Bilim Dalı, Ankara, 2015 .

53. ÖDEN, UTKU MEHMET, Kurklareli İli ve Çevresindeki İnanç Merkezleri, Trakya Üniversitesi, Sosyal Bilimler Enstitüsü, Türk Dili ve Edebiyatı Anabilim Dalı, Türk Edebiyatı Bilim Dalı, Edirne, 2013.

54. ÖN, GÜLŞAH , Korklareli İli Tiğ Dantelleri ve Yeni Tasarmlar, Gazi Üniversitesi, Güzel Sanatlar Enstitüsü, Geleneksel Türk Sanatları Anasanat Dalı, Ankara, 2017.

55. ÖNCÜ, BURAK, Okul Öncesi Yöneticilerinin Algllanan Liderlik Stilleri İle Okul Öncesi Öğretmenlerinin Yaşadıkları Örgütsel Sessizlik Arasındaki İlişkinin İncelenmesi (Krrklareli İli Örneği), Bahçeşehir Üniversitesi, Eğitim Bilimleri Enstitüsü, Eğitim Yönetimi ve Planlaması Anabilim Dalı, İstanbul, 2017. 
56. ÖZDOĞAN, HAMIDE, Krrklareli İli Köy Adlarn İncelemesi, Kırklareli Üniversitesi, Sosyal Bilimler Enstitüsü, Türk Dili ve Edebiyatı Anabilim Dalı, Kırıklareli, 2016.

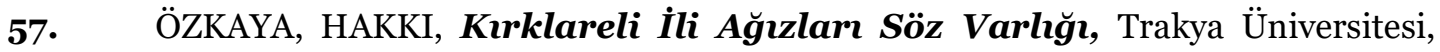
Sosyal Bilimler Enstitüsü, Türk Dili ve Edebiyatı Anabilim Dalı, Türk Dili Bilim Dalı, Edirne, 2013.

58. ÖZTÜRK, MUHAMMED, Örgütsel Bă̆hlhk ve Să̆hk Çalsşanlarmm Örgütsel Bağhlık Düzeyleri: Krrklareli Örneği, Beykent Üniversitesi, Sosyal Bilimler Enstitüsü, İşletme Yönetimi Anabilim Dalı, Hastane ve Sağlık Kur. Yön. Bilim Dalı, İstanbul, 2013.

59. ÖZYURT, ŞENIZ, Lüleburgaz Sokullu Mehmed Paşa Külliyesi, Hacettepe Üniversitesi, Sosyal Bilimler Enstitüsü, Ankara, 1989.

6o. PAJO, AYKUT, Türkiye'deki Cittaslow Kentleri Yerel Yönetimlerinin Destinasyon Pazarlaması Uygulamaları: Vize İlçesi Örneği, Kurklareli Üniversitesi, Sosyal Bilimler Enstitüsü, İşletme Anabilim Dalı, Kırklareli, 2015.

61. PURODRAN, NIHAN, Temettuat Defterlerine Göre Lüleburgaz'in SosyoEkonomik ve Demografik Yapısı, Trakya Üniversitesi, Sosyal Bilimler Enstitüsü, Tarih Anabilim Dalı, Yakınçă̆ Tarihi Bilim Dalı, Edirne, 2010.

62. SARI, EMRE, Sergen İle Demirköy Arasında Kalan Sahamm Fiziki Coğrafyası, Selçuk Üniversitesi, Sosyal Bilimler Enstitüsü, Eğitim Bilimleri Bölümü, Ortaöğretim Sosyal Alanlar Eğitimi Anabilim Dalı, Coğrafya Öğretmenliği Bilim Dalı, Konya, 2009.

63. SIZAN, ESRA, Kırklareli'de Boşnak Halk Kültürrü, Trakya Üniversitesi, Sosyal Bilimler Enstitüsü, Balkan Çalışmaları Anabilim Dalı, Edirne, 2016.

64. ŞANLI, CEVDET, Kurklareli İli Merkez İlçe Köyleri Ăğzları (İncelemeMetin), Trakya Üniversitesi, Sosyal Bilimler Enstitüsü, Edirne, 1990.

65. ŞEN, ŞEVKET, Babaeski'de Şehirsel Gelişme, İstanbul Üniversitesi, Sosyal Bilimler Enstitüsü, İstanbul, 2001.

66. ŞEVIK, İBRAHIM, Küçük İşletmelerin Türk Ekonomisindeki Yeri, Sorunları ve Karklareli İlindeki Küçük İşletmelerin Sorunlarının Araştırılması, İstanbul Üniversitesi, Sosyal Bilimler Enstitüsü, İstanbul, 1993.

67. TAYSI, KEMAL, Muhasebe Meslek Mensuplarmda Tükenmişlik Sendromu Üzerine Karklareli İlinde Bir Araştorma, Trakya Üniversitesi, Sosyal Bilimler Enstitüsü, İşletme Anabilim Dalı, Edirne, 2012.

68. TOP, HILAL, Sağhk Hizmetlerinde Toplam Kalite Yönetiminin Çalışanlara Etkisi: Krrklareli İli Sağhlk Çahşanları Örneği, Beykent Üniversitesi, Sosyal Bilimler Enstitüsü, İşletme Yönetimi Anabilim Dalı, Hastane ve Sağlık Kur. Yön. Bilim Dalı, İstanbul, 2013.

69. TOPCUOĞLU, HÜSEYIN, Hastalarn Ăğzz ve Diş Sağhğı Hizmetlerinden Yararlanma Durumlarn ve Tatmin Düzeyleri (Krrklareli Örneği), Beykent Üniversitesi, Sosyal Bilimler Enstitüsü, İşletme Anabilim Dalı, Hastane ve Sağlık Kur. Yön. Bilim Dalı, İstanbul, 2014.

7o. TOPRAK, ASLI OKAY, Bölgesel Kalkanma ve Üniversiteler: Kirklareli Örneğii, İstanbul Üniversitesi, Sosyal Bilimler Enstitüsü, İktisat Anabilim Dalı, İktisat Politikası Bilim Dalı, İstanbul, 2012. 
71. TOPTAŞ, BARIŞ, Kırklareli Merkez İlçe ve Köylerindeki Gayri Müslim Eserleri, Trakya Üniversitesi, Sosyal Bilimler Enstitüsü, Sanat Tarihi Anabilim Dalı, Edirne, 2012.

72. TURHAN, DİLEK, Okul Yöneticilerin Örgütsel Problemlere Karşı Bilimsel Problem Çözme Tekniklerini Uygulama Düzeyleri: Krrklareli Örneği, Fatih Üniversitesi, Sosyal Bilimler Enstitüsü, Eğitim Yönetimi, Teftişi, Planlaması ve Eko. Anabilim Dal, İstanbul, 2015.

73. TUZKAYA, EMİ, Krrklareli Müzesi'ndeki Osmanl Dönemi Sikkeleri: Cilt-I, Cilt-II, Trakya Üniversitesi, Sosyal Bilimler Enstitüsü, Sanat Tarihi Anabilim Dalı, Edirne, 2010.

74. UĞURLU, ALİRIZA UĞUR, İlköğretim Sekizinci Sinı Öğgrencilerinin Çok Değişkenli Olarak İncelenmesi [Kirklareli İli Merkez İlçe Örneği], Yeditepe Üniversitesi, Sosyal Bilimler Enstitüsü, Eğitim Yönetimi ve Denetimi Anabilim Dalı, İstanbul, 2010.

75. ÜÇTEPE, EKREM, Kirklareli-Lüleburgaz Arasındaki Orman Kalıntıları, İstanbul Üniversitesi, Sosyal Bilimler Enstitüsü, İstanbul, 1993.

76. ÜNAL, MELTEM, II. Dünya Savaşı: Trakya'da Yeşilyurt Gazetesinde Krrklareli, 1943, Kırklareli Üniversitesi, Sosyal Bilimler Enstitüsü, Tarih Anabilim Dalı, Kırıklareli, 2016.

77. YENIADA, GÖKHAN, Kirklareli Lüleburgaz TEK Güzel Sanatlar Lisesi'ndeki Keman Ĕğitiminin İncelenmesi, Trakya Üniversitesi, Sosyal Bilimler Enstitüsü, Müzik Anasanat Dalı, Edirne, 2017.

78. YERLIKAYA, HACER, Yönetici İletişim Becerilerinin Çalş̧an Motivasyonu ve İş Tatmini Üzerine Etkileri (Korklareli Üniversitesi Örneği), Beykent Üniversitesi, Sosyal Bilimler Enstitüsü, İşletme Yönetimi Anabilim Dalı, Hastane ve Sağlık Kur. Yön. Bilim Dalı, İstanbul, 2017.

79. YILDIZ, AHMET, Lüleburgaz Lise Coğrafya Öğretmenlerinin Cŏgrafya Öğretim Yaklaşımları, Süleyman Demirel Üniversitesi, Sosyal Bilimleri Enstitüsü, Coğrafya Anabilim Dalı, Isparta, 2015.

80. YILMAZ, ZÜLKÜF, Krrklareli İli Stnırları İçinde Kalan Tümü̈lüsler, Trakya Üniversitesi, Sosyal Bilimler Enstitüsü, Edirne, 1996.

\section{Doktora Tezleri}

1. KARAKUZU, ALİ, Sağhlk Çalışanlarında Motivasyon ve Motivasyonu Etkileyen Faktörler: Krrklareli Örneği, Beykent Üniversitesi, Sosyal Bilimler Enstitüsü, İşletme Yönetimi Anabilim Dalı, Hastane ve Sağlık Kur. Yön. Bilim Dalı, İstanbul, 2013.

2. ARI, ILKNUR, Tarihöncesi Sit Alanlarnda Kültürr Mirası Yönetimi Krrklareli Höyüğ̈̈ Sit Alanı ve Kültür Mirası Yönetimi, İstanbul Üniversitesi, Sosyal Bilimler Enstitüsü, Arkeoloji Anabilim Dalı, Prehistorya Bilim Dalı, İstanbul, 2009.

3. DOĞRUÖZ, TÜRKAN, Milli Mücadelede Krrklareli, İstanbul Üniversitesi, Atatürk İlkeleri ve İnkılap Tarihi Enstitüsü, Atatürk İlkeleri ve İnkılap Tarihi Anabilim Dalı, İstanbul, 2005.

4. TIMOR, AYŞE NUR, Orta Büyükklükteki Şehirler ve Lüleburgaz Örneği, İstanbul Üniversitesi, Sosyal Bilimler Enstitüsü, Beşeri ve İktisadi Coğrafya Anabilim Dalı, İstanbul, 1992.

5. SAĞLAMBİLEN, OKAN, Geleneksel Türk Müziği Çalgılar Ĕğitiminde Lüleburgaz Yöresi Kaba Zurna İcracılarmm Çalgıya İlişkin Görüş ve 
Uygulamalarmm İncelenmesi, Gazi Üniversitesi, Eğitim Bilimleri Enstitüsü, Güzel Sanatlar Eğitimi Anabilim Dalı, Müzik Öğretmenliği Bilim Dalı, Ankara, 2014.

\section{İngilizce Yazılmış Yüksek Lisans Tezleri}

1. KAYA, HARUN, The Byzantine Fortnesses Of Yoğuntaş, Keçikalesi, Punarhisar In The Kurklareli Region / Kurklareli'ndeki Bizans Kaleleri (Yoğuntaş, Keçikalesi, Pmarhisar), İhsan Doğramacı Bilkent Üniversitesi, Sosyal Bilimler Enstitüsü, İstanbul, 1997.

2. UÇAN, LALE, Ottoman Kirklareli and İts Hinterland İn The 19th Century / 19. Yüzyılda Osmanlı Kırklareli'si ve Onun Hinterlandı, Boğaziçi Üniversitesi, Sosyal Bilimler Enstitüsü, Tarih Anabilim Dalı, İstanbul, 2002.

3. UZUN, BEGÜM, Gypsies, The Roma and Justice Claims: The Case of Lüleburgaz / Çingeneler, Romanlar ve Adalet Talepleri: Lüleburgaz Örneği, Boğaziçi Üniversitesi, Sosyal Bilimler Enstitüsü, Uluslararası İlişkiler Bölümü, Siyaset Bilimi ve Uluslararası İlişkiler Anabilim Dalı, Siyaset ve Sosyal Bilimler Bilim Dalı, İstanbul, 2008.

4. YÜREK, NILAY, Encounters and Perceptions: A Descriptive Study On The Local and Kurdish Residents Of Lüleburgaz / Karşılaşmalar ve Algzlar: Lüleburgaz'da Yaşayan Yerli Nüfus ve Kürt Nüfusa Yönelik Betimleyici Bir Çalışma, Sabancı Üniversitesi, Sosyal Bilimler Enstitüsü, Uyuşmazlık Analizi ve Çözümü Anabilim Dal, İstanbul, 2014.

\section{Değerlendirme}

Kırklareli ve ilçeleri üzerine yapılmış olan, sosyal ve beşeri bilimlerle ilgili yüksek lisans ve doktora tezlerinin bibliyografik listesini sunduk. Şimdi de bu çalışmaların sahiplerinin isimleri, tezlerin ulaşılabilirlik durumları, türleri, tez sahiplerinin çalışmalarını hangi konu başlı̆̆ıyla nitelendirdikleri ve hangi dilde yazıldıklarını gösteren tablomuza bakalım. Bu tablo, görsel bütünlük sağlama açısından da faydalı olacaktır.

\begin{tabular}{|c|c|c|c|c|}
\hline AD SOYAD & DURUMU & KONU & TÜR & DÍL \\
\hline ADEM DERTLI & Kisitll & Tarih & Yüksek Lisans & Türkçe \\
\hline AHMET CAN & Açık & Ĕğitim ve Öğretim-Íşletme & Yüksek Lisans & Türkçe \\
\hline AHMET YILDIZ & Açık & Coğrafya & Yüksek Lisans & Türkçe \\
\hline AKİF ÇEVİK & Kisitlı & Tarih & Yüksek Lisans & Türkçe \\
\hline ALİ BALCI & Tübess & Coğrafya & Doktora & Türkçe \\
\hline ALI KARAKUZU & Açık & $\begin{array}{l}\text { Hastaneler-Sağlık Kurumları } \\
\text { Yönetimi-İşletme }\end{array}$ & Yüksek Lisans & Türkçe \\
\hline $\begin{array}{l}\text { ALİRIZA UĞUR } \\
\text { UĞURLU }\end{array}$ & Açık & Ĕgitim ve Ö̌̆gretim & Yüksek Lisans & Türkçe \\
\hline $\begin{array}{l}\text { ALPARSLAN } \\
\text { BÜLBÜL }\end{array}$ & Açık & $\begin{array}{l}\text { Hastaneler-Sağlık Kurumları } \\
\text { Yönetimi-İşletme }\end{array}$ & Yüksek Lisans & Türkçe \\
\hline $\begin{array}{l}\text { ALPARSLAN } \\
\text { ERDER }\end{array}$ & Tübess & Coğrafya & Yüksek Lisans & Türkçe \\
\hline $\begin{array}{l}\text { ASLI OKAY } \\
\text { TOPRAK }\end{array}$ & Açık & Ekonomi & Yüksek Lisans & Türkçe \\
\hline AYDIN CIDAN & Açık & Coğrafya-Kamu Yönetimi & Yüksek Lisans & Türkçe \\
\hline AYKUT AYDIN & Açık & $\begin{array}{l}\text { Çalışma Ekonomisi ve Endüstri } \\
\text { İlişkileri }\end{array}$ & Yüksek Lisans & Türkçe \\
\hline AYKUT PAJO & Kisitlı & Turizm-İşletme & Yüksek Lisans & Türkçe \\
\hline AYSUN AKDAĞ & Tübess & Müzecilik & Yüksek Lisans & Türkçe \\
\hline AYŞE DURMAZ & Açık & Ĕgitim ve Öğretim & Yüksek Lisans & Türkçe \\
\hline
\end{tabular}




\begin{tabular}{|c|c|c|c|c|}
\hline $\begin{array}{l}\text { AYŞE NUR } \\
\text { TIMOR }\end{array}$ & Kisitlı & Coğrafya & Doktora & Türkçe \\
\hline BARIŞ TOPTAŞ & Açık & Sanat Tarihi & Yüksek Lisans & Türkçe \\
\hline BEGÜM UZUN & Açık & Siyasal Bilimler & Yüksek Lisans & İngilizce \\
\hline BETÜL KONYAR & Kisitll & Türk Dili ve Edebiyatı & Yüksek Lisans & Türkçe \\
\hline BURAK ÖNCÜ & Açık & Ĕgitim ve Öğretim & Yüksek Lisans & Türkçe \\
\hline $\begin{array}{l}\text { BURCU BURNAZ } \\
\text { KABAKCI }\end{array}$ & Açık & Sosyoloji-Tarih & Yüksek Lisans & Türkçe \\
\hline $\begin{array}{l}\text { BÜLENT } \\
\text { HÜNERLI }\end{array}$ & Açık & Türk Dili ve Edebiyatı & Yüksek Lisans & Türkçe \\
\hline $\begin{array}{l}\text { CAN AHMET } \\
\text { GENERAL }\end{array}$ & Açlk & Siyasal Bilimler-İşletme & Yüksek Lisans & Türkçe \\
\hline $\begin{array}{l}\text { CEMİLE } \\
\text { GÜRFİDAN }\end{array}$ & Açık & $\begin{array}{l}\text { Aile Hekimliği-Hastaneler-Sağlık } \\
\text { Kurumları Yönetimi }\end{array}$ & Yüksek Lisans & Türkçe \\
\hline CEVDET ȘANLI & Tübess & Türk Dili ve Edebiyatı & Yüksek Lisans & Türkçe \\
\hline $\begin{array}{l}\text { ÇİĞDEM } \\
\text { AKARDERE } \\
\text { UZUN }\end{array}$ & Tübess & Coğrafya & Yüksek Lisans & Türkçe \\
\hline $\begin{array}{l}\text { DAVUT } \\
\text { AKYÜZOĞLU }\end{array}$ & Açık & Ĕ̆itim ve Öğretim & Yüksek Lisans & Türkçe \\
\hline DİLEK ATICI & Kisitli & Türk Dili ve Edebiyatı & Yüksek Lisans & Türkçe \\
\hline DİLEK TURHAN & Açık & Ĕgitim ve Öğretim & Yüksek Lisans & Türkçe \\
\hline EDIP İPEK & Açık & Tarih & Yüksek Lisans & Türkçe \\
\hline EKREM ÜÇTEPE & Tübess & Coğrafya & Yüksek Lisans & Türkçe \\
\hline $\begin{array}{l}\text { ELÇİN } \\
\text { BAYRAKTAROĞL } \\
\text { U }\end{array}$ & Açık & İşletme & Yüksek Lisans & Türkçe \\
\hline EMEL DENIZ & Kisitll & Sanat Tarihi & Yüksek Lisans & Türkçe \\
\hline EMEL KURTÇU & Tübess & Ekonomi & Yüksek Lisans & Türkçe \\
\hline EMÍR TUZKAYA & Açık & Sanat Tarihi & Yüksek Lisans & Türkçe \\
\hline EMRE SARI & Açık & Coğrafya & Yüksek Lisans & Türkçe \\
\hline ESRA SIZAN & Kisitll & Halk Bilimi-Folklor & Yüksek Lisans & Türkçe \\
\hline EZGİ GÖL & Açık & Eğitim ve Öğretim & Yüksek Lisans & Türkçe \\
\hline FIRAT MENTEŞ & Açık & Din-Sosyoloji & Yüksek Lisans & Türkçe \\
\hline $\begin{array}{l}\text { GÖKHAN } \\
\text { DURAK }\end{array}$ & Açık & İşletme & Yüksek Lisans & Türkçe \\
\hline $\begin{array}{l}\text { GÖKHAN } \\
\text { YENİADA }\end{array}$ & Kisitlı & Müzik & Yüksek Lisans & Türkçe \\
\hline $\begin{array}{l}\text { GÖNÜL EKŞİ } \\
\text { GÖRPEOĞLU }\end{array}$ & Tübess & Coğrafya & Yüksek Lisans & Türkçe \\
\hline $\begin{array}{l}\text { GÜLBAHAR } \\
\text { MUTLUER }\end{array}$ & Açık & El Sanatları & Yüksek Lisans & Türkçe \\
\hline GÜLSEN BİNGÖL & Açık & $\begin{array}{l}\text { Hemşirelik-Sağlık Kurumları } \\
\text { Yönetimi-İşletme }\end{array}$ & Yüksek Lisans & Türkçe \\
\hline $\begin{array}{l}\text { GÜLSEN } \\
\text { ERGİNAL }\end{array}$ & Açık & Coğrafya & Yüksek Lisans & Türkçe \\
\hline GÜLŞAH ÖN & Açlk & El Sanatları & Yüksek Lisans & Türkçe \\
\hline $\begin{array}{l}\text { HACER } \\
\text { YERLİKAYA }\end{array}$ & Açık & Sağlık Kurumları Yönetimi & Yüksek Lisans & Türkçe \\
\hline HAKKI ÖZKAYA & Açlk & Türk Dili ve Edebiyatı & Yüksek Lisans & Türkçe \\
\hline $\begin{array}{l}\text { HAMIDE } \\
\text { ÖZDOĞAN }\end{array}$ & Açlk & Türk Dili ve Edebiyatı & Yüksek Lisans & Türkçe \\
\hline HARUN KAYA & Açık & Sanat Tarihi & Yüksek Lisans & Íngilizce \\
\hline HİLAL TOP & Açık & $\begin{array}{l}\text { Hastaneler-Sağlık Kurumları } \\
\text { Yönetimi-İsletme }\end{array}$ & Yüksek Lisans & Türkçe \\
\hline $\begin{array}{l}\text { HÜSEYIN } \\
\text { TOPCUOĞLU }\end{array}$ & Açık & Sağlık Kurumları Yönetimi-İşletme & Yüksek Lisans & Türkçe \\
\hline İBRAHİM ŞEVİK & Tübess & İşletme & Yüksek Lisans & Türkçe \\
\hline ÍLKNUR ARI & Açlk & Arkeoloji & Doktora & Türkçe \\
\hline İLKNUR EROL & Açık & $\begin{array}{l}\text { Hastaneler-Sağlık Kurumları } \\
\text { Yönetimi }\end{array}$ & Yüksek Lisans & Türkçe \\
\hline İLKNUR KULELİ & Açık & Ĕgitim ve Öğretim & Yüksek Lisans & Türkçe \\
\hline
\end{tabular}




\begin{tabular}{|c|c|c|c|c|}
\hline KEMAL TAYSI & Açık & İşletme & Yüksek Lisans & Türkçe \\
\hline LALE UÇAN & Açık & Sanat Tarihi & Yüksek Lisans & İngilizce \\
\hline $\begin{array}{l}\text { MEHMET } \\
\text { ALTUNTAŞ }\end{array}$ & Tübess & Sanat Tarihi & Yüksek Lisans & Türkçe \\
\hline $\begin{array}{l}\text { MEHMET } \\
\text { ERDINCC } \\
\text { KADIOĞLU }\end{array}$ & Tübess & Müzik & Yüksek Lisans & Türkçe \\
\hline MELEK KIRTIL & Kisitlı & Sosyoloji & Yüksek Lisans & Türkçe \\
\hline MELTEM ÜNAL & Kisitlı & Tarih & Yüksek Lisans & Türkçe \\
\hline $\begin{array}{l}\text { MUHAMMED } \\
\text { ÖZTÜRK }\end{array}$ & Açlk & $\begin{array}{l}\text { Hastaneler-Sağlık Kurumları } \\
\text { Yönetimi-İșletme }\end{array}$ & Yüksek Lisans & Türkçe \\
\hline $\begin{array}{l}\text { NAZAN } \\
\text { KARADAĞ }\end{array}$ & Açık & $\begin{array}{l}\text { Hemşirelik-Sağlık Kurumları } \\
\text { Yönetimi-İşletme }\end{array}$ & Yüksek Lisans & Türkçe \\
\hline $\begin{array}{l}\text { NİHAN } \\
\text { PURODRAN }\end{array}$ & Açık & Demografi-Tarih & Yüksek Lisans & Türkçe \\
\hline NÍLAY YÜREK & Açık & Psikoloji-Sosyoloji & Yüksek Lisans & İngilizce \\
\hline NURİ GÜÇTEKİN & Tübess & Tarih & Yüksek Lisans & Türkçe \\
\hline $\begin{array}{l}\text { OKAN } \\
\text { SAĞLAMBİLEN }\end{array}$ & Açlk & Müzik & Doktora & Türkçe \\
\hline $\begin{array}{l}\text { OSMAN } \\
\text { KOCAAGA }\end{array}$ & Açık & Kamu Yönetimi & Yüksek Lisans & Türkçe \\
\hline $\begin{array}{l}\text { OYA ESIN } \\
\text { KAYMAZ }\end{array}$ & Tübess & Coğrafya & Yüksek Lisans & Türkçe \\
\hline $\begin{array}{l}\text { OZAN } \\
\text { DEMİRALP }\end{array}$ & Açık & Ĕ̆itim ve Öğretim & Yüksek Lisans & Türkçe \\
\hline ÖMER ÇOLAK & Açık & Tarih & Yüksek Lisans & Türkçe \\
\hline $\begin{array}{l}\text { PINAR ÖZDEMİR } \\
\text { KARACA }\end{array}$ & Açık & Bilim ve Teknoloji-Ĕ̆itim ve Öğretim & Yüksek Lisans & Türkçe \\
\hline $\begin{array}{l}\text { SARIYE } \\
\text { KARAKUZU }\end{array}$ & Açık & $\begin{array}{l}\text { Kamu Yönetimi-Sağlık Kurumları } \\
\text { Yönetimi-İşletme }\end{array}$ & Yüksek Lisans & Türkçe \\
\hline SEYHAN ÇERÇİ & Açık & $\begin{array}{l}\text { Hastaneler-Hemşirelik-Sağlık } \\
\text { Kurumları Yönetimi }\end{array}$ & Yüksek Lisans & Türkçe \\
\hline SIMEN KAVAK & Tübess & Arkeoloji & Yüksek Lisans & Türkçe \\
\hline ŞENIZZ ÖZYURT & Tübess & Sanat Tarihi & Yüksek Lisans & Türkçe \\
\hline ŞEVKET ŞEN & Tübess & Coğrafya & Yüksek Lisans & Türkçe \\
\hline $\begin{array}{l}\text { ŞÜKRAN } \\
\text { MERCAN } \\
\text { MORGÜL }\end{array}$ & Açık & Turizm & Yüksek Lisans & Türkçe \\
\hline TAHA EĞRI & Açık & Ekonomi & Yüksek Lisans & Türkçe \\
\hline TÜLIN KIVILCIM & Tübess & Coğrafya & Yüksek Lisans & Türkçe \\
\hline $\begin{array}{l}\text { TÜRKAN } \\
\text { DOĞRUÖZ }\end{array}$ & Açık & Türk İnkılap Tarihi & Doktora & Türkçe \\
\hline $\begin{array}{l}\text { UTKU MEHMET } \\
\text { ÖDEN }\end{array}$ & Açık & Halk Bilimi-Folklor & Yüksek Lisans & Türkçe \\
\hline $\begin{array}{l}\text { YUNUS } \\
\text { KULOĞLU }\end{array}$ & Açık & $\begin{array}{l}\text { Halk Sağlığı-Sağlık Kurumları } \\
\text { Yönetimi-Uyuşturucu Alışkanlığı ve } \\
\text { Alkolizm }\end{array}$ & Yüksek Lisans & Türkçe \\
\hline YUSUF İNCE & Kisitlı & Turizm & Yüksek Lisans & Türkçe \\
\hline YÜKSEL KAŞTAN & Tübess & Ekonomi & Yüksek Lisans & Türkçe \\
\hline YÜKSEL ÇABAZ & Açık & Ĕgitim ve Őğretim & Yüksek Lisans & Türkçe \\
\hline ZAFER KAT & Kisitli & Tarih & Yüksek Lisans & Türkçe \\
\hline ZÜLKÜF YILMAZ & Tübess & Arkeoloji & Yüksek Lisans & Türkçe \\
\hline
\end{tabular}

Tablo 2. Tezlere Dair Bibliyografik Tablo

Yukarıdaki tabloda, bibliyografyasını sunduğumuz Kırklareli ve ilçelerine dair sosyal ve beşeri bilimler alanlarında yapılmış olan yüksek lisans ve doktora tezlerin yazar ad ve soyadları, tezlerin ulaşılabilirlik durumları, konu adlandırmaları, türleri ve hangi dilde yazıldıkları yer almaktadır. İlk sütunda tez sahiplerinin isimleri yer almıştır. İkinci sütunda ise bu tezlerin ulaşlabilirlik durumları gösterilmiştir. 
“Açık” olarak nitelendirilen tezler, Yükseköğretim Kurulu Başkanlığı’nın herkesin erişimine açık olan "Ulusal Tez Merkezi" tez sorgulama sayfasından² indirilebilip okunabilen ve incelenebilen tezler manasına gelmektedir. Tezlerin tam metinlerinin internet üzerinden PDF formatında olacak şekilde araştırmacıların hizmetine sunulması;

- Tezlere kolay, serbest ve hızlı erişmenin sağlanması,

- Bilimsel ve akademik araştırmalarda tekrarların önlenmesi,

- Bilimsel bilginin daha etkin bir biçimde yayımlanması,

- Intihal durumlarının denetlenmesi ve engellenmesi,

konularında önemli katkılar sağlayacaktır.

Yükseköğretim Kurulu'nun hazırlamış olduğu kılavuzda tezlerden faydalanabilme ölçüsü: "Araştırmacılar, Ulusal Tez Merkezi internet adresi üzerinden hizmete sunulan tezlerden 5/12/1951 tarihli ve 5846 sayll Fikir ve Sanat Eserleri Kanununun 35 inci ve 38 inci maddeleri çerçevesinde yararlanır.” şeklinde ifade edilmiştir (T.C Yükseköğretim Kurulu, 2010, s. 1).

"Kısıtlı" olarak betimlenen tezler ise tez sahibi tarafından belirli bir süreliğine kullanıcıların erişimine kapalı olan tezleri ifade etmektedir. Bu kısıtlama eser sahibinin isteğine göre 3 ay ile 3 yll arasında değişebilmektedir. Bu süre, 2007 öncesinde en fazla 5 yll iken 2007 yllında, tezle ilişkili patent başvurusu veya tezin bir yayıncı tarafından yayınlanma sürecinde olma durumu gibi sebeplerle, süreli olarak en fazla 3 yl olarak ertelenmesi Yükseköğretim Kurulu tarafından kabul edilmiştir. Bu kararın alınmasındaki en büyük sebep: Lisansüstü tezlerin yazılma gayesinin, ortaya konulan araştırma çalışmasının ve sonuçlarının araştırma ve bilim dünyasının istifadesine sunulması olduğu savından hareketle, tüm lisansüstü tezlerin makul sebepler haricinde hiçbir kısıtlama olmaksızın tüm araştırmacıların erişimine açık olması öngörülmüştür (T.C Yükseköğretim Kurulu, 2010, s. 1-2). Tezin kopyalanması endişesinin de, tezin araştırmacıların ulaşımına açılmasının engellenmesi için makul, geçerli ve kabul edilebilir bir sebep olmadı ̆̆ı vurgulanmıştır. Böylelikle yapılan her çalışmanın belirli bir süre sonunda herkesin erişimine açık olması sağlanarak bilimsel ve akademik dolaşım özgürlüğü sağlanması amaçlanmıştır.

“Tübess” ibaresinin açılımı ise "Türkiye Belge Sağlama Sistemi” demektir.3 Türkiye Cumhuriyeti Kültür ve Turizm Bakanlığı himayesinde TÜBİTAK-ULAKBİM tarafından oluşturulmuş bir sistemdir. Tübess ibaresi olan tezlere ulaşmak için araştırmacılar kendi bağlı oldukları kuruma, bilgi merkezlerine veya herhangi bir kütüphaneye müracaat ederek bu sistemden faydalanabilirler. Bu sistem sadece bahsi geçen kütüphane bilgi merkezleri ya da kurumlarda çalışan sorumlu belge sağlama personeli tarafından kullanılabilmektedir. Yazarlarından yayımlama izni alınmamış olan tezlerin; 5846 sayılı Fikir ve Sanat Eserleri Kanunu'nun şahsen kullanma hakkını düzenleyen 38 inci maddesindeki "Bütün fikir ve sanat eserlerinin, kar amacı güdülmeksizin şahsen kullanmaya mahsus çoğaltılması mümkündür. Ancak, bu çoğaltma hak sahibinin meşru menfaatlerine hakh bir sebep olmadan zarar veremez ya da eserden normal yararlanmaya aykırı olamaz" hükmüne dayanarak Yükseköğretim Yürütme Kurulu'nun 13.05.2014 tarihli oturumunda alınan karar ile TÜBİTAK-ULAKBİM tarafından işletilmekte olan Türkiye Belge Sağlama ve Ödünç Verme Sistemi (TÜBESS) üzerinden araştırma hizmetine açılmıştır. Yalnız burada bazı önemli uyarılar söz konusudur. TÜBESS Katılım Protokolünün4 İstek Yapan Kurumun Yükümlülükleri Bölümünün (6.3.5) maddesinde yer alan "Sağlayıcı kütüphane tarafından

Bu sitenin adresi : https://tez.yok.gov.tr/UlusalTezMerkezi/

Detaylı bilgi ve inceleme için: http://www.tubess.gov.tr/sss.html\#kim

Protokolün tamamı için: http://www.tubess.gov.tr/protokol.pdf 
iletilen elektronik belgeleri (makale vd.), son kullanıcıya basılı formatta teslim etmek, bu belgeleri bilgisayar sistemlerinden silmek ve hiçbir suretle arşivlememek" hükmüne uygun bir şekilde sağlanması şart koşulmuştur.

İncelediğimiz lisansüstü tezlerin erişilebilirlik durumlarını gösteren grafik aşağıdaki gibidir.

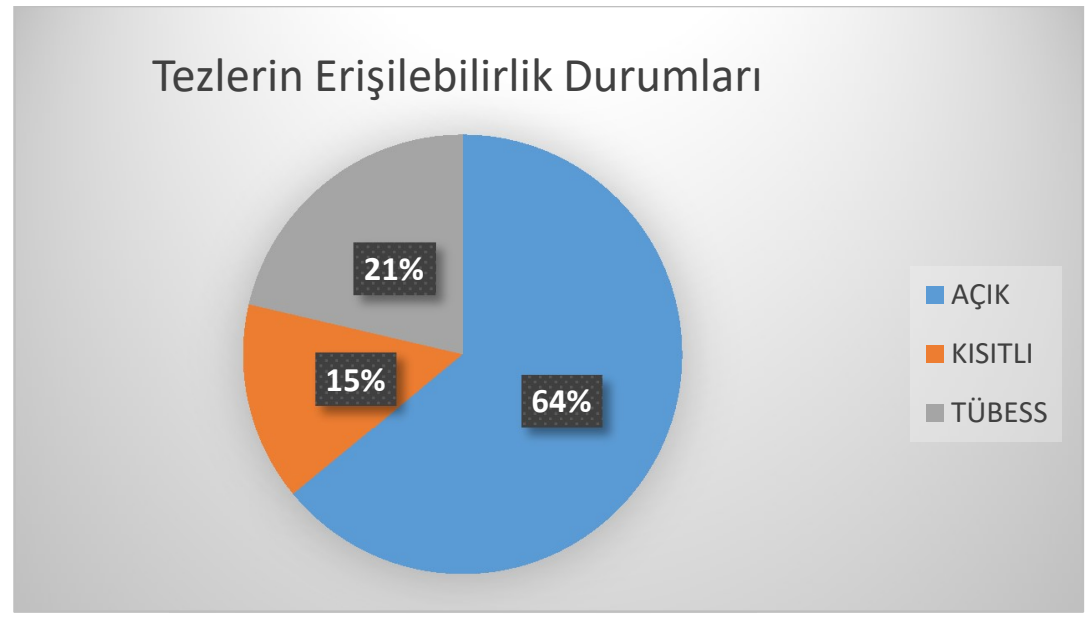

Grafik 1. Lisansütü Tezlerin Erişilebilirlik Oranları

Kırklareli ve ilçeleri üzerine sosyal ve beşeri bilimler alanında; “4’ü İngilizce olmak üzere toplam 84 adet Yüksek Lisans Tezi, tamamı Türkçe olmak üzere 5 adet Doktora Tezi” yazılmıştır. Toplam 89 adet tezin içinde 57 tanesinin durumu "Açık", 13 tanesi "Kısıtll", 19 tanesinin ulaşlabilirlik durumu ise "Tübess" üzerinden sağlanmaktadır. Bu sayıların toplam sayıya olan oranları yukarıdaki grafikte belirtilmiştir.

Tablonun üçüncü sütununda yer alan "KONU” başlığında, bibliyografyasını sunduğumuz lisansüstü tez sahiplerinin çalışmalarını hangi konu başlıklarıyla nitelendirildikleri görülmektedir. Konu başlıkları, tamamen tez sahipleri tarafından belirlenmiş olan başlıklardır. Bu yüzden olsa gerek benzer konularda yapılmış çalışmalar farklı konu başlıklarıyla veya birden çok yardımcı alanın dahil edilmesiyle birlikte adlandırılmıştır. Bu konu başlıkları tezlerin içeriğiyle ilgili genel bir bilgi sahibi olmak ve tez arama noktasında filtreleme seçeneğiyle aramayı daraltıp doğru kaynağa ulaşmak açısından yardımcı olan ek bilgilerdir.

\begin{tabular}{|c|l|}
\hline ADET & KONU BAŞLIĞI \\
\hline $\mathbf{1 2}$ & Coğrafya \\
\hline $\mathbf{9}$ & Ĕ̆itim ve Öğretim \\
\hline $\mathbf{7}$ & Sanat Tarihi \\
\hline $\mathbf{7}$ & Tarih \\
\hline $\mathbf{6}$ & Türk Dili ve Edebiyatı \\
\hline $\mathbf{4}$ & Ekonomi \\
\hline $\mathbf{4}$ & Hastaneler-Să̆lık Kurumları Yönetimi-İsletme \\
\hline $\mathbf{4}$ & İşletme \\
\hline
\end{tabular}




\begin{tabular}{|c|c|}
\hline 3 & Arkeoloji \\
\hline 3 & Müzik \\
\hline 2 & El Sanatları \\
\hline 2 & Halk Bilimi-Folklor \\
\hline 2 & Hemşirelik-Sağlık Kurumları Yönetimi-İşletme \\
\hline 2 & Turizm \\
\hline $\mathbf{1}$ & Aile Hekimliği-Hastaneler-Sağlık Kurumları Yönetimi \\
\hline $\mathbf{1}$ & Bilim ve Teknoloji-Ĕgitim ve Öğretim \\
\hline $\mathbf{1}$ & Coğrafya-Kamu Yönetimi \\
\hline $\mathbf{1}$ & Çalışma Ekonomisi ve Endüstri İlişkileri \\
\hline $\mathbf{1}$ & Demografi-Tarih \\
\hline $\mathbf{1}$ & Din-Sosyoloji \\
\hline $\mathbf{1}$ & Ĕ̆itim ve Öğretim-İşletme \\
\hline $\mathbf{1}$ & Halk Sağlığı-Sağlık Kurumları Yönetimi-Uyuşturucu Alışkanlığı ve Alkolizm \\
\hline $\mathbf{1}$ & Hastaneler-Hemşirelik-Sağlık Kurumları Yönetimi \\
\hline $\mathbf{1}$ & Hastaneler-Sağlık Kurumları Yönetimi \\
\hline $\mathbf{1}$ & Kamu Yönetimi \\
\hline $\mathbf{1}$ & Kamu Yönetimi-Sağlık Kurumları Yönetimi-İşletme \\
\hline $\mathbf{1}$ & Müzecilik \\
\hline $\mathbf{1}$ & Psikoloji-Sosyoloji \\
\hline $\mathbf{1}$ & Sağlık Kurumları Yönetimi \\
\hline $\mathbf{1}$ & Sağllk Kurumları Yönetimi-İşletme \\
\hline $\mathbf{1}$ & Siyasal Bilimler \\
\hline $\mathbf{1}$ & Siyasal Bilimler-İşletme \\
\hline $\mathbf{1}$ & Sosyoloji \\
\hline $\mathbf{1}$ & Sosyoloji-Tarih \\
\hline $\mathbf{1}$ & Turizm-İşletme \\
\hline $\mathbf{1}$ & Türk İnkılap Tarihi \\
\hline
\end{tabular}

\section{Tablo 3. Hangi Konu Başlığıyla Kaç Tez Yazıldığını Gösteren Tablo}

Tabloda yer alan bazı konu başlıkları tez sahiplerinin belirledikleri konu başlıklarıdır. Dolayısıyla bir ya da daha fazla konu başlığı olan çalışmalar birbirleriyle ilintili olabilmektedir. Bu açıdan bakınca Kırklareli ve ilçeleri için sosyal ve beşeri bilimler alanlarından en fazla tez yazılan konular 17 çalışmayla İşletme, alt dalları ve ilintili olduğu bölümler, 13 çalışmayla Coğrafya, 11 çalışmayla Ĕ̆itim ve Öğretim, 10 çalışmayla Tarih ve alt dalları, 9 çalışmayla El Sanatları ve genel anlamda Sanat Tarihi, 8 çalışmayla da Türk Dili ve Edebiyatı ile Halkbilim-Folklor çalışmaları göze çarpmaktadır.

Yapılan çalışmalarda bir diğer inceleme alanımız da Kırklareli ve ilçeleri için yazılan tezlerin hangi yılda kaç tane yazıldı ̆̆ı, bir başka ifadeyle, bu il ve ilçelerimizin akademik araştırma sahası olmasının tarihsel grafiğidir. Bilimsel anlamda söz konusu il ve ilçelerimizin araştırmacıların merakını cezbetme oranı 
yıllara göre belirlenmiştir. İncelediğimiz lisansüstü tezlerin yazıldıkları yılları gösteren grafik aşağıdaki gibidir.

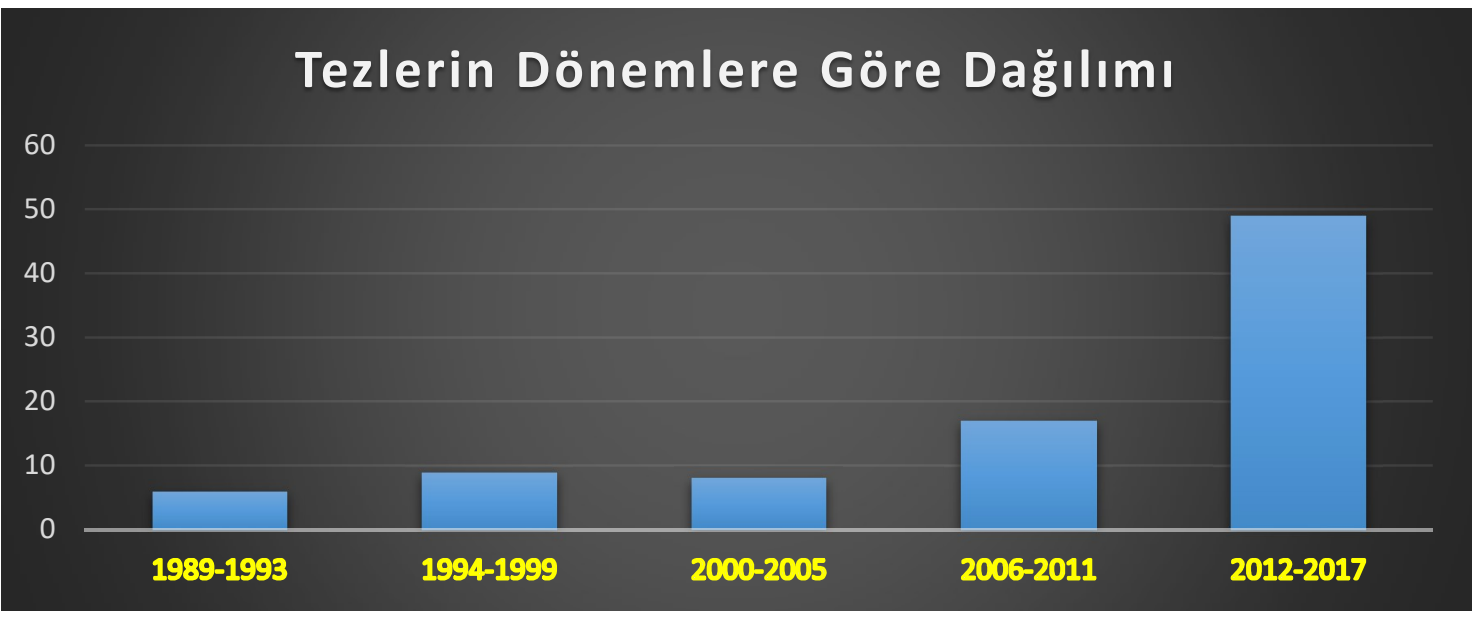

\section{Grafik 2. Lisansüstü Tezlerin 5’er Yıllık Dönemlere Göre Sayıları ve Grafiği}

Yukarıdaki grafikte incelenen lisansüstü tezlerin 5'er yıllık dönemlere göre sayıları ve grafiği gösterilmiştir. Söz konusu il ve ilçeler için sosyal ve beşeri bilimler alanlarında yazılan ve tespit edilen ilk lisansüstü tez 1989 yllına aittir. Bu çalışmalar 2005 yllına kadar durağan bir görüntü çizmekle beraber 2006 yllından itibaren araştırmaların ve çalışmaların hızla artış gösterdiğini görmekteyiz. 1989 - 1993 yılları arasında 6,1994 - 1999 yılları arasında 9, 2000 - 2005 seneleri arasında 8 çalışma yapılmıştır. Bu sayılar bu yıldan sonra artış göstererek 2006 - 2011 yılları arasında 17 ve 2012'den günümüze kadar da 49 yüksek lisans ve doktora tezi yazılmıştır.

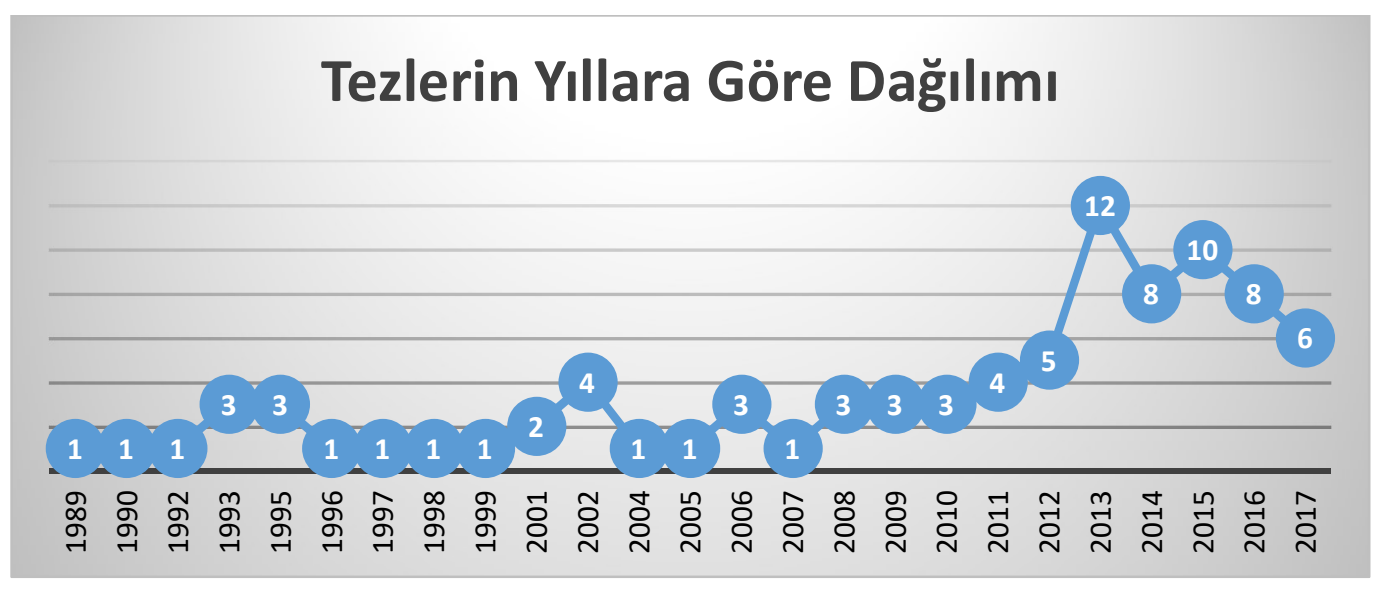

Grafik 3. Lisansüstü Çalışmaların Yıllara Göre Sayılarını Gösteren Grafik

Kırklareli il ve ilçelerine dair inceleme yaptığımız alanlarla ilgili ilk olarak 1989'da yapılan lisansüstü çalışmalar, 2010'lu yıllara kadar durağan bir şekilde devam etmiş, bu yıllardan günümüze kadar ise gözle görülür büyük bir artış yaşanmıştır. Özellikle 2013 yılında bu alanlarda 12 adet lisansüstü tez tespit edilmiştir. 21. yüzyıl şimdiden bilim, bilgi ve teknoloji çağı olarak adlandırılmaktadır. Dolayısıyla ileride daha da artmasını umduğumuz ve tahmin ettiğimiz Kırklareli ve ilçelerine dair bilimsel, akademik çalışmaların bu durumdan etkilenmemesi zaten söz konusu olamazdı. Elbette bu durumda ülkemizin yükseköğretim politikasının payı büyüktür. Artan nüfusumuz, genç nüfusun fazlalı̆̆ı, yeni açılan 
üniversitelerle birlikte sayısı 112 olan devlet üniversitesi ve sayısı 65 olan vakıf üniversiteleri bunda etkili olmuştur. Sayısı 7 milyonu aşan öğrenci sayısı ve 1635 fakülte, 466 yüksekokul, 955 meslek yüksekokulu, 673 enstitü ve 2894 araştırma ve uygulama merkezi gibi devasa rakamlara ulaşan yükseköğretim bakiyemiz ${ }^{5}$ bilimsel ve akademik olarak hem niceliksel hem de niteliksel anlamda katma değer sağlamaya devam etmektedir.

Söz konusu il ve ilçeler için yapılan lisansüstü çalışmaların belirli üniversitelerde yoğunlaştığını gözlemledik. Bundan hareketle sosyal ve beşeri bilimler özelinde incelediğimiz çalışmaların hangi üniversitede kaç adet yapıldığına dair verileri ortaya koymanın doğru olacağını düşünüyoruz.

\begin{tabular}{|cl|}
\hline ADET & ÜNIVERSITELER \\
\hline $\mathbf{2 1}$ & Trakya Üniversitesi \\
\hline $\mathbf{1 7}$ & İstanbul Üniversitesi \\
\hline $\mathbf{1 3}$ & Beykent Üniversitesi \\
\hline $\mathbf{9}$ & Kurklareli Üniversitesi \\
\hline $\mathbf{4}$ & Gazi Üniversitesi \\
\hline $\mathbf{3}$ & Hacettepe Üniversitesi \\
\hline $\mathbf{2}$ & Boğaziçi Üniversitesi \\
\hline $\mathbf{2}$ & Çanakkale Onsekiz Mart Üniversitesi \\
\hline $\mathbf{2}$ & Dokuz Eylül Üniversitesi \\
\hline $\mathbf{2}$ & Selçuk Üniversitesi \\
\hline $\mathbf{2}$ & Yeditepe Üniversitesi \\
\hline $\mathbf{1}$ & Afyon Kocatepe Üniversitesi \\
\hline $\mathbf{1}$ & Ankara Üniversitesi \\
\hline $\mathbf{1}$ & Bahçeşehir Üniversitesi \\
\hline $\mathbf{1}$ & Fatih Üniversitesi \\
\hline $\mathbf{1}$ & İhsan Doğramaci Bilkent Üniversitesi \\
\hline $\mathbf{1}$ & İstanbul Teknik Üniversitesi \\
\hline $\mathbf{1}$ & Kahramanmaraş Sütçü İmam Üniversitesi \\
\hline $\mathbf{1}$ & Marmara Üniversitesi \\
\hline $\mathbf{1}$ & Ondokuz Mays Üniversitesi \\
\hline $\mathbf{1}$ & Sabanci Üniversitesi \\
\hline $\mathbf{1}$ & Süleyman Demirel Üniversitesi \\
\hline & Ylldı Teknik Üniversitesi \\
\hline
\end{tabular}

Tablo 4. Üniversitelere Göre Tez Sayıları

İncelediğimiz ve bibliyografyasını sunduğumuz 89 lisansüstü tez, 23 farklı üniversitede yazılmıştır. Bunların içerisinde Trakya Üniversitesi 21 tez ile başı çekmektedir. Bunu 17 çalışma ile İstanbul Üniversitesi takip ederken 12 farklı üniversitede ise sadece 1 adet tez yazılmıştır. Diğer üniversiteler bu rakamlar arasında muhtelif sayıda tezlerle katkıda bulunmuşlardır. Şehrin kendi üniversitesinin 10 yıllık bir kurumsal mazisi olmasına rağmen dördüncü sırada bulunması, aslında üniversitelerin kuruluş

5 Daha detaylı bilgi ve istatistikler için bkz: https://istatistik.yok.gov.tr/ 
yıllarına göre oransal anlamda bakıldığında, bilimsel olarak en çok katkı sunan ve çalışma yapılan üniversite olduğu gerçeği dikkatlerden kaçmamaktadır. Bu durum da daha önce belirttiğimiz gibi bir şehrin üniversitesinin o şehre ve yöreye ne denli hizmet ettiğini ve bilimsel verilerle o ilin ve yörenin kalkınmasına katkı sunduğunu destekler niteliktedir. Nitekim ilk sırada yer alan Trakya Üniversitesi de Kırklareli'nin komşu ili olup en çok çalışmanın orada yapıldığı gerçeğide bize bunu kanıtlamaktadır.

\section{Sonuç}

Bu çalışmamızda Kırklareli ve ilçeleri üzerine sosyal ve beşeri bilimler alanlarında yazılmış olan yüksek lisans ve doktora tezlerinin bibliyografyasını sistematik bir şekilde sunmaya ve bu verilerden yola çıarak bazı tespitlerde bulunmaya çalıştık. Bunu yaparken konumuz olan Kırklareli hakkında coğrafi konumu ve özelliklerden başlayarak genel bilgiler verip, tarihi, kültürel ve sanatsal yönlerine değindik. Şehrin zirai olarak önemli bir merkez sayılabileceğini söyleyebiliriz. Kırklareli isminin art zamanlı durumuna dair de bazı bilgi ve bulgulardan bahsettik. Bu il ve ilçelerimizin nüfusuyla ilgili istatiksel verileri de sunarak il ve ilçelerin demografik yönlerine değinmiş olduk.

Bibliyografyalar bilim tarihi boyunca ana başvuru kaynakları olma misyonunu üstlenmişlerdir. Biz de bibliyografyanın kelime kökeni, terim anlamı ve tarihsel gelişimi üzerinde durup önemine dair bilgiler aktardık. Sonrasında ise sosyal ve beşeri bilimlerin ne demek olduğunu, hangi alanları kapsadığını, neden böyle bir konu kısıtlaması yaptığımızı izah etmeye çaba gösterdik. Sosyal ve beşeri bilimlerin doğa ve fen bilimlerinden ayrıldığını ve sınırlarının net olmadığını, bu işin uzmanlarınca da gerek kapsama alanı gerekse de içerik ve yöntemleriyle ilgili kesin bir fikir birliğine varılmadığını görmekteyiz.

Çalışmamızın da ana konusunu teşkil eden Kırklareli ve ilçeleri üzerine yazılmış yüksek lisans ve doktora tezlerinin bibliyografyasını sıraladık. Bu tezlerin eser sahiplerinin adlarını, bu tezlerin ulaşılabilirlik durumlarını, tez sahiplerinin çalışmalarına uygun gördükleri konu başlıklarını, türlerini ve hangi dilde yazıldıklarını gösteren bir tablo ile görsel bütünlüğü de yakalamayı hedefledik. Buna göre söz konusu il ve ilçelerimizle ilgili olarak; 4'ü İngilizce olmak üzere toplam 84 adet yüksek lisans tezi, tamamı Türkçe olmak üzere 5 adet doktora tezi yazıldığını ve bu toplam 89 adet tezin içinde 57 tanesinin durumunun “Açık", 13 tanesinin "Kısıtlı”, 19 tanesinin ise ulaşılabilirlik durumunun “Tübess" üzerinden sağlandığını tespit ettik. Açık ibaresinin herkesçe ulaşılabilir demek olduğunu ve bunun kanuni altyapısının ne olduğunu, kısıtlı ibaresinin, eser sahiplerince en fazla 3 yıl olmak üzere erişime kapatması demek olduğunu açıkladık. Erişilebilirlik durumları arasında tübess ibaresinin ise Türkiye Belge Sağlama Sistemi'nin kısaltması olduğunu ve Tübitak-Ulakbim tarafından, eski tezlerin, araştırmacıların istifadesine sunmak için hayata geçirilen bir sistem olduğunu açıkladık. Tüm bunları ise tezlerin erişilebilirlik durumlarını gösteren bir grafik ile destekledik.

Söz konusu 89 adet tezin konu başlıklarına dair bir tablo sunup en çok hangi konu başlıklarında tezler yazıldığını ortaya koyduk. Buna göre en çok işletme, coğrafya ve eğitim-öğretim bilim alanlarının diğer tüm alanlara nazaran çok daha fazla tercih edilmiş olduğunu ifade ettik. Yapılan çalışmaların yıllara göre durumunu da belirleyip süreç içinde akademik ilgi odağı olma eğrisini belirlemeye çalıştık. Buna göre söz konusu il ve ilçelere dair sosyal ve beşeri bilimler alanlarında ilk tezin 1989 yılında yazıldığını ve günümüze kadar hangi 5 yıllık dönemler arasında bu çalışmaların kaç tane olduğunu gösteren bir tablo ortaya koyduk. Tespit edilen ilk tezden günümüze kadar en fazla çalışma 12 adet tez ile 2011 yllında yapılmıştır. 1989'dan günümüze kadar yıl yıl kaç tane çalışma olduğunu gösteren grafiği de çalışmamıza ekledik. 2010'lu yıllarla birlikte Kırklareli il ve ilçelerine olan akademik ilginin arttığını söyleyebiliriz. Bu ilginin nedenlerini söz konusu il ve ilçelerimiz özelinde aradığımız gibi ülkemizin genel durumu, 
eğitim politikası, yükseköğretimimizin rakamsal verileriyle de doğru orantılı olduğunu iddia edip bunu kanıtlamak maksadıyla da somut resmi verilerden faydalanarak ortaya koyduk.

Yazılan yüksek lisans tezlerinin hangi üniversitelerde yazıldığı da önemliydi bizim için. Bundan ötürü hangi üniversitemizde kaç adet tez yazıldığını tespit edip bunu gösteren bir tablo ile durumu somutlaştırdık. Buna göre; 21 tez ile en yüksek çalışma Trakya Üniversitesi'nde yapılmıştır. Bunu 17 tez ile İstanbul Üniversitesi ve 13 tez ile Beykent Üniversitesi takip etmiştir. 10 yll gibi yeni kabul edilebilecek bir mazisi olmasına rağmen şehrin ismiyle müsemma olan Kırklareli Üniversitesi'nin de 9 çalışmayla bu sıralamayı takip ettiğini söylemek gerekir. Zira bu rakam tüm üniversiteler arasında yıllara göre oransal anlamda en yüksek rakamdır. Bu da, üniversitelerin kuruldukları şehirlere bilimsel anlamda katkı sunmasındaki en net kanıtıdır.

Kırklareli, tarihi çok eskilere dayanan bir ilimizdir. Verimli topraklarıyla, coğrafi güzellikleri ve bulunduğu konum itibariyle de dikkate değerdir. Sahip olduğu tüm bu özelliklerle büyük bir potansiyeli bünyesinde barındırmaktadır. Özellikle doğal ve tarihi güzellikleriyle turizm, verimli toprak arazileriyle tarım ve bulunduğu yer itibariyle de sanayi ve ticari olarak gelişmeye ve büyümeye namzet bir şehrimizdir. Yeni kurulan üniversitesi, artan genç nüfus oranı, sahip olduğu dokusuyla daha pek çok araştırmacı için ilgi alanı olmaya devam edeceğinden şüphe yoktur. Nitekim incelediğimiz çalışmalarla da bilimsel ve akademik ilginin sürekli bir artış gösterdiğini gözlemlemiştik. Bu durumun artarak devam edeceğini ve de etmesi gerektiğini vurgulamak isteriz.

\section{Kaynakça}

Akın, V. (1997). Kırklareli Adının Tarihçesi. Pamukkale Üniversitesi Eğitim Fakültesi Dergisi(2).

Demir, Ö., \& Acar, M. (1992). Sosyal Bilimler Sözlüğ̈̈. İstanbul: Ağaç Yayıncılık.

Doğruöz, V. T. (2005). Milli Mücadelede Kırklareli, Yayınlanmış Doktora Tezi. İstanbul: İstanbul Üniversitesi.

Larousse, M. (1992). Meydan Larousse Büyük Lugat ve Ansiklopedi (Cilt 3). İstanbul: Sabah Gazetesi.

Parlatır, İ., Gözaydın, N., Zülfikar, H., Aksu, T., Türkmen, S., \& Yılmaz, Y. (1998). Türkçe Sözlük (Cilt 2). Ankara: Türk Dil Kurumu.

Seyyar, A. (2002). Sosyal Siyaset Terimleri (Ansiklopedik Sözlük). İstanbul: Beta Yayınları.

T.C Yükseköğretim Kurulu. (2010). Yükseköğretim Kurumlarında Hazırlanan Lisansüstü Tezlerin İnternet Üzerinden Derlenmesi Hakkında Kılavuz. Ankara: T.C Yükseköğretim Kurulu.

T.C. Kırklareli Valiliğ̈i Çevre ve Şehircilik İl Müdürlüğü, Ç. İ. (2016). KIrklareli İli 2015 Yllh Çevre Durum Raporu. Kırklareli: T.C Kırklareli Valiliği Çevre ve Şehircilik İl Müdürlüğü.

Tuncel, M. (1988). Kıklareli. Türkiye Diyanet Vakfi İslam Ansiklopedisi. içinde Ankara: Türkiye Diyanet Vakfi Yayınları.

TÜİK. (2016). "Konularma Göre İstatistikler, Adrese Dayah Nüfus Kayıt Sistemi". 12 13, 2017 tarihinde Türkiye İstatistik Kurumu: http://www.tuik.gov.tr adresinden alındı. 